\title{
Non-Invasive Approach to Investigate the Mineralogy and Production Technology of the Mosaic Tesserae from the Roman Domus of Villa San Pancrazio (Taormina, Italy)
}

\author{
Olivia Gomez-Laserna ${ }^{1, *(\mathbb{D}}$, Anna Irto $\left.{ }^{2}{ }^{(}\right)$, Pablo Irizar ${ }^{1}$, Gabriele Lando ${ }^{2}{ }^{(}$, Clemente Bretti $^{2}$, \\ Irantzu Martinez-Arkarazo ${ }^{1}$, Lorenzo Campagna ${ }^{3}$ and Paola Cardiano ${ }^{2, *(D)}$ \\ 1 Department of Analytical Chemistry, University of the Basque Country (UPV/EHU), Barrio Sarriena s/n, \\ Leioa, E-48080 Bilbao, Spain; pablo.irizar@ehu.eus (P.I.); irantzu.martinez@ehu.eus (I.M.-A.) \\ 2 Department of Chemical, Biological, Pharmaceutical and Environmental Sciences, University of Messina, \\ Viale F. Stagno d'Alcontres 31, I-98166 Messina, Italy; airto@unime.it (A.I.); glando@unime.it (G.L.); \\ cbretti@unime.it (C.B.) \\ 3 Department of Ancient and Modern Cultures, University of Messina, Polo Universitario dell'Annunziata, \\ I-98168 Messina, Italy; lcampagna@unime.it \\ * Correspondence: olivia.gomez@ehu.eus (O.G.-L.); pcardiano@unime.it (P.C.)
}

Citation: Gomez-Laserna, O.; Irto, A.; Irizar, P.; Lando, G.; Bretti, C.; Martinez-Arkarazo, I.; Campagna, L.; Cardiano, P. Non-Invasive Approach to Investigate the Mineralogy and Production Technology of the Mosaic Tesserae from the Roman Domus of Villa San Pancrazio (Taormina, Italy). Crystals 2021, 11, 1423. https:// doi.org/10.3390/cryst11111423

Academic Editors: Claudia Scatigno, Giulia Festa and Maite Maguregui

Received: 11 November 2021

Accepted: 18 November 2021

Published: 21 November 2021

Publisher's Note: MDPI stays neutra with regard to jurisdictional claims in published maps and institutional affiliations.

Copyright: (c) 2021 by the authors. Licensee MDPI, Basel, Switzerland. This article is an open access article distributed under the terms and conditions of the Creative Commons Attribution (CC BY) license (https:// creativecommons.org/licenses/by/ $4.0 /)$.

\begin{abstract}
The archaeological excavations at Villa San Pancrazio (Taormina, Italy) are bringing to light a vast Roman-Imperial residential quarter featuring luxurious dwellings decorated with wall paintings and mosaic floors, pointing it out as one of the most significant archaeological sites of the city. The polychrome and black and white mosaics recovered date back to the middle Imperial period, during the 2 nd century AD. This work deals with the first archaeometric investigations of the materials employed for the tesserae production with the aim of elucidating the mineralogical composition and obtaining analytical evidence that can contribute to extracting information related to their production technology. For that purpose, a non-invasive methodology, based on micro energy dispersive $\mathrm{X}$-ray fluorescence ( $\mu$-EDXRF) spectrometry and Raman spectroscopy, was used to characterize a wide selection of stone, ceramic and glass tesserae. Chemometric tools were exploited to manage the large set of elemental data collected on black and white lithic samples, providing essential clues for the subsequent investigations. The results evidenced the employment of natural lithotypes (calcareous sedimentary, dolomitic and volcanic) local and imported, and also artificial materials, such as ceramic made firing magnesium-rich clays, soda-lime-silica glasses made with different opacifying and coloring agents (such as calcium antimoniate, cobalt and copper).
\end{abstract}

Keywords: Raman spectroscopy; EDXRF; chemometric analysis; Roman Taormina; Roman mosaics

\section{Introduction}

In recent decades, research on Roman architecture and architectural decoration has broadened its horizons to the study of production processes, in particular in the fields of stone and stucco decoration and wall painting; therefore it has offered important contributions to the reconstruction of social and economic dynamics in both public and private building activities. Even in the field of mosaics, the traditional iconographic and stylistic approach has been recently supported by multidisciplinary investigations on the origin of raw materials, as well as on the techniques of execution, division of labor and costs [1]. Literature on these aspects is more consistent for some areas of the Roman world, particularly in the provinces of north-western Europe $[2,3]$. On the contrary, the enormous potential of Sicily has been only minimally exploited to date [4,5], despite the fact that the island boasts a rich corpus of mosaics from the Roman age [6], belonging above all to rich urban domus and extra-urban villas, within which mosaics, as well as wall paintings, are a fundamental indicator of the owner's economic, social and ideological status. 
More generally, however, from the results of such studies historical and archaeological considerations on the role of commissioners, on the organization of workshops, on the methods of obtaining and processing raw materials and on the working procedures have only rarely been developed. Therefore, many questions about the production process of mosaics in the Roman world still remain open and, at least for some of them, the development of multidisciplinary research can offer important contributions, especially as regards the technical, economic and commercial aspects connected to the selection and manufacturing of raw materials. From the perspective of acquiring useful data for this area of research on mosaics, the case study of the Hellenistic-Roman residential area of Villa San Pancrazio in Taormina (Sicily) offers optimal conditions thanks to the high number of wellpreserved mosaics, mostly bichromatic (black and white) but with some monochromatic (white) and polychromatic specimens too; furthermore, recent excavations have made it possible to acquire a deep overall knowledge of the archaeological and monumental context [7]. Accordingly, an interdisciplinary team selected a variety of suitable tesserae and designed an integrated archaeological and chemical exploration approach, with the aim of obtaining the first archaeometric clues as a rational support for further in situ investigations.

In this regard, as is well established for archaeometric investigations on mosaics of historical and cultural value, the employed analytical methodology should be mainly based on non-destructive techniques allowing, at the same time, the analysis of a large number of samples in order to provide statistically significant results. More in detail, the investigation should ensure the analysis of the tesserae as they are, avoiding any damage, carrying out in situ non-invasive studies or, if strictly required, moving the samples to the laboratory for non-destructive tests and then relocating them to their original position for the mosaic restoration [8,9]. Another critical issue to be considered should be the minimization of any consequence coming from the samples' exposure to an environment different from the original one, or from their moving to the laboratory, since the abrupt change in the complex soil-air coupled preservation conditions, which ensured tesserae conservation for centuries, could activate alteration processes (cracking, salt enrichment, biofouling, etc.) and accelerate their deterioration [10-13]. According to the cited requirements, the combination of X-ray fluorescence (XRF) and Raman spectroscopy has been so far largely exploited since it allows the non-destructive collection of a large amount of data in a relatively short time providing, at the same time, high chemical specificity [14-16]. In this sense, a variety of archaeometric studies [17] have shown the benefits of the synergic combination of the above techniques as a powerful tool for a reliable characterization of the most common matrices found in archaeological excavations such as metals [9,18], pigments [19-21], mirrors [22], stones $[23,24]$, ceramics $[25,26]$ or glasses $[8,27,28]$. Among them, literature reports specifically dealing with mosaics which evidenced that XRF and Raman spectroscopy were successfully exploited not only to characterize bulk materials, but also to robustly identify trace components related, for instance, to a natural stone color, or compounds used as flux, or even dyes and opacifiers present within the tesserae matrix [24,29].

In this work, energy-dispersive X-ray fluorescence (EDXRF) spectrometry was selected as the first analytical technique to explore the compositional major and minor elements of the stone, ceramic and glass tesserae recovered from the Roman domus being excavated in the Villa San Pancrazio in Taormina. Furthermore, since most of the mosaics from the site are bichromatic, a principal component analysis (PCA) was performed on the elemental data obtained from white and black tesserae to relate their composition to the sampling location, as well as to manage, on a rational basis, a suitable protocol for subsequent targeted molecular investigations. Then, for a deeper insight into the sample exploration, a Raman analysis was carried out, employing different lasers to improve the quality of spectral signals, since they are often compromised by fluorescence effects caused either by the occurring of clays or organic compounds into the samples, or organic matter and dust due to external agents and burial conditions $[16,30]$. Accordingly, the fluorescence background can be reduced by the selection of the laser excitation wavelength based on 
the sample color and nature, sometimes allowing the enhancement of the Raman signal by several orders of magnitude. For example, the green one is the most suitable for green and blue tesserae, whose color is commonly related to the presence of green earths, minerals and pigments of natural or synthetic origin, or to the incorporation of transition elements within the glass structure $[9,30,31]$. Only for cases of strong fluorescence, in which the use of the photobleaching technique (overexposure to laser) or the laser line change were not sufficient to acquire the proper signals, or when the identification of compounds having low Raman scattering was required [32,33], was the micro-destructive X-ray powder diffraction (XRD) analysis used to support and/or deepen the hypotheses raised [34].

\section{The Archaeological Context}

The ancient Tauromenium is located in correspondence with the present Taormina, on the eastern coast of Sicily, just over twenty kilometers from the north-eastern slopes of Mount Etna. In the Roman-Imperial age it was one of the most flourishing urban centers of the island [35]. The origins of the city date back to the mid-4th century BC but it is from the following century that Taormina experienced a period of economic and political growth, thanks to the resources of the territory and its very favorable strategic and commercial position, controlling the transit routes in the Strait of Messina [36]. The importance of the city is also reflected in the size and monumentality of the Hellenistic urban layout, which was maintained with few changes until the end of antiquity. The public areas and monuments of the Hellenistic-Roman city have been the subject of archaeological investigations for over a century and are also well known to a wider public, specifically the spectacular theater. Private houses are less known, being documented above all by emergency excavations of the past century, which have brought to light in different areas of the modern urban center the remains of wall structures, floor mosaics and wall paintings clearly belonging to medium-high level residences, mostly from the Imperial Age (1st-3rd century AD) [6,37-40]. The better-known examples of Tauromenium Roman houses have been excavated within the park of Villa San Pancrazio, a hotel built in the early 1900s on the northern limit of the ancient and modern town [35] (Figures S1 and S2). In the past century, the regional Superintendencies of Syracuse, and then of Messina, excavated a large house of the Imperial Age (Domus 1) in the north-western sector of the park [41-43] (Figure S3); starting from 2015, the University of Messina resumed and expanded investigations in the area, completing the excavation of Domus 1 and bringing to light parts of three other adjoining houses, still under excavation (Domus 2, 2a and 3) [7] (Figure S3). The above-mentioned domus spread on terraces sloping down a steep hillside and were part of a residential area built between the 1st century BC and the 1st century AD. In this period, judging from archaeological evidence, the construction can be referred as on the highest terraces of Domus 3, of which only a few rooms have been investigated so far, and of Domus 2, of which instead a larger surface has been excavated [7,35]. Only later, around the middle of the 2 nd century AD, Domus 1 was built on the lower terrace. In the same period, it seems possible to date some rooms excavated in the uppermost terrace of the area, belonging to another, still almost unknown house, provisionally called Domus 2a.

The most widely excavated houses, Domus 1 and Domus 2, are high-class residences, as indicated above all by the overall size and the number of rooms, which in both houses are distributed on the four sides of an open central courtyard bordered by columns. Another indicator is the presence of floors and wall decorations of a certain commitment, more or less elaborate according to the function of the individual rooms [44]. In the oldest of the two, Domus 2, the decoration of the interior spaces is entrusted above all to wall paintings (Figure S4), while the floors are made of simple mortar, opus signinum or brick; in the excavated part of the house no mosaic floors have been found. In Domus 1, on the other hand, the spaces of the house intended for representative functions have both high-quality wall paintings (unfortunately poorly preserved) (Figure S5) and very well-preserved floors with polychrome or black and white mosaics, characterized by various decorative patterns. 
The ambulatories that surround the four sides of the Domus 1 central court exhibit black and white geometric mosaics, employing differing patterns on each side: the north and south ambulatories have a scale pattern, the western has squares and lozenges with swastikas, the eastern has laced circles (Figure 1). All these patterns were widely used throughout the Imperial Age. The rooms opening on the north and west ambulatories of the court have pavements of other types, thus showing a non-representative role, apart from Room 1, which lies on a higher level on the west side of the house.
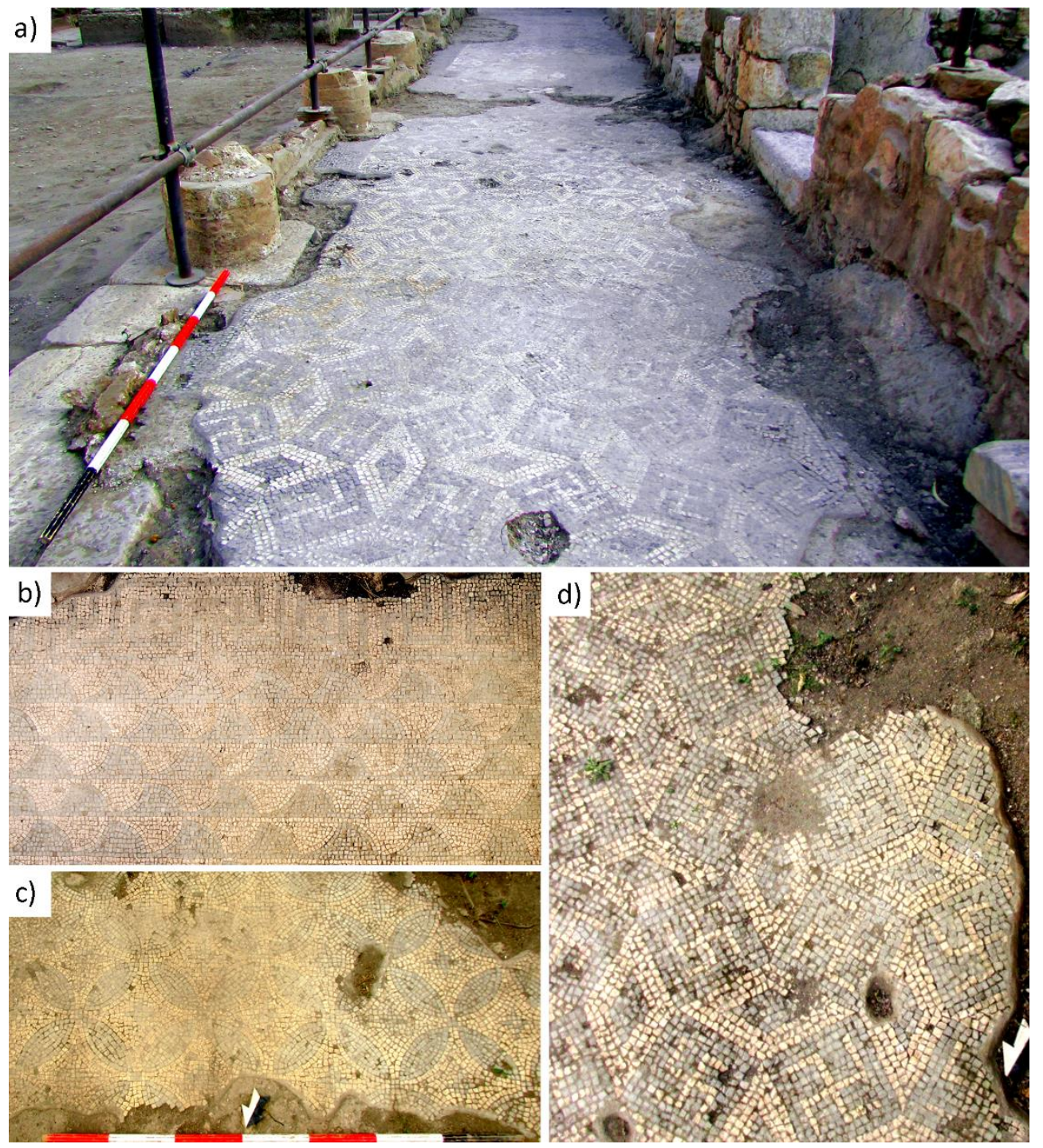

Figure 1. Domus 1; (a) the west ambulatory of the courtyard, view from the north; (b-d) geometric patterns of the black and white mosaics of the north, west and east ambulatories, respectively, around the courtyard.

The refined black and white mosaic of Room 1 is the only figurative example so far discovered in Domus 1: the center of the room shows a squared pseudo-emblem $(0.56 \mathrm{~m} \times 0.58 \mathrm{~m})$ depicting a male figure striking a vine tree with a double-edged axe (Figure 2). The scene has been identified by several scholars as a representation of the myth of Lycurgus and Ambrosia according to an iconographic scheme common in the 2nd century AD [6]. Around the central scene, the mosaic follows a uniform geometric pattern of black squares arranged obliquely and linked by the corners thus constituting horizontal and vertical white lozenges. 

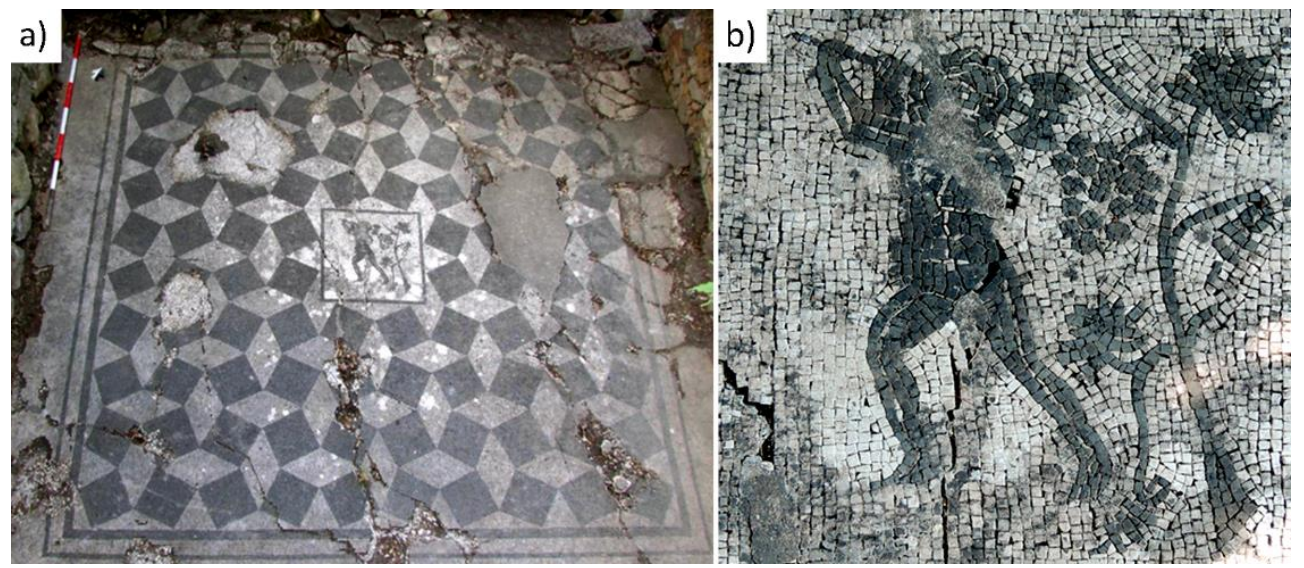

Figure 2. Domus 1, black and white mosaic of Room 1; (a) general view; and (b) particular view of the central pseudo-emblem.

The southern ambulatory of the court gives access to three adjacent rooms $(16,17$, and 18) with a lavish wall and floor decoration. The back wall in each of them, preserved up to $3.75 \mathrm{~m}$ in height, is arranged with a semi-circular statue niche covered by poorly preserved mosaics (Figure 3a). In the central Room 17, the biggest of the three, a small archaeological test trench carried on the north side revealed part of a polychrome mosaic with white, red, brown and blue tesserae (Figure 3b).

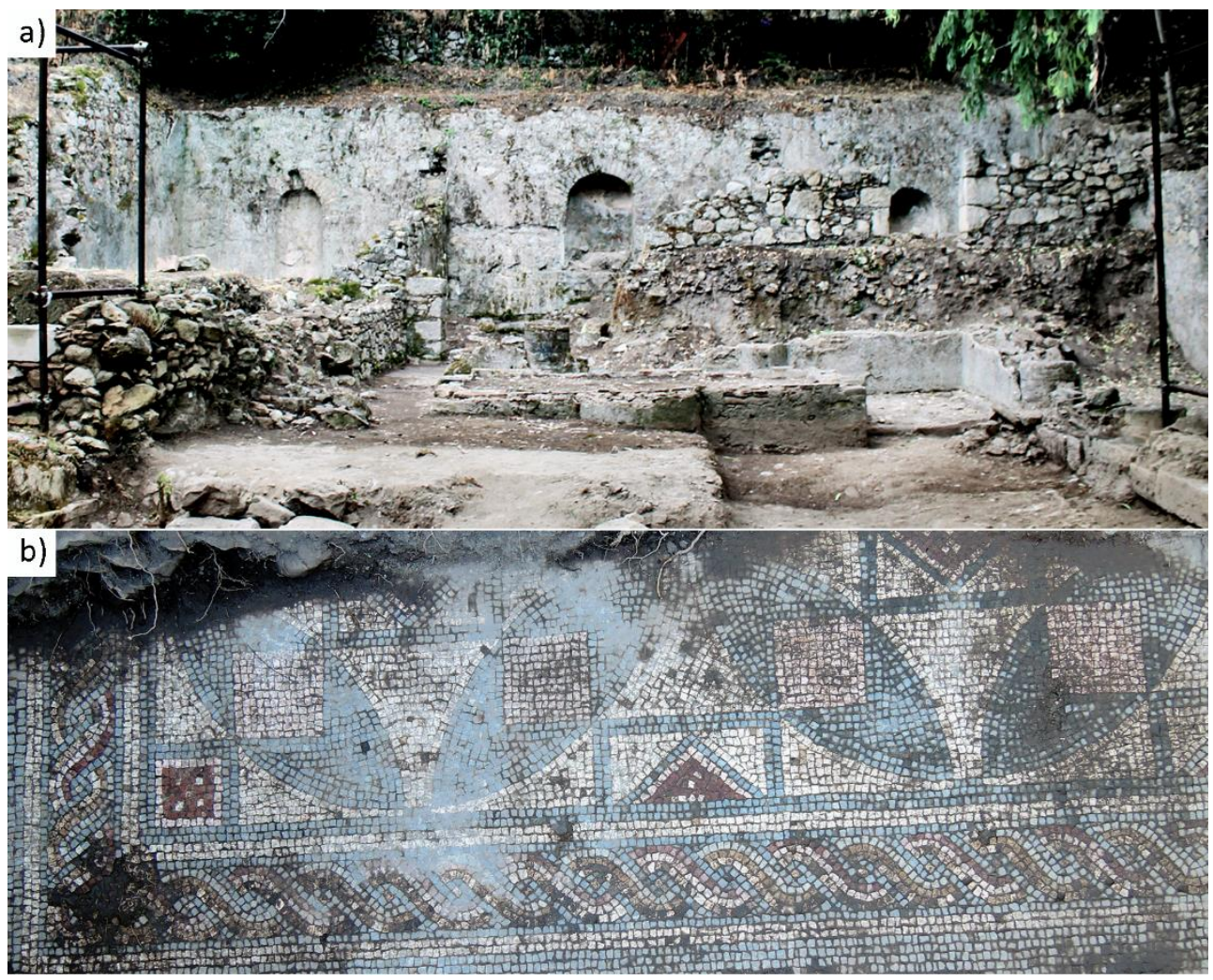

Figure 3. Domus 1; (a) view of the southern aisle of the court with Rooms 16, 17 and 18; and (b) polychrome mosaic in Room 17.

The pattern displays a simple guilloche cornice framing a geometric composition with four tied circles with a four-petalled rose in the center. Although the mosaic has not yet been fully excavated, both the complexity of the design and the quality of execution can be already guessed, making it the highest-level example of the entire residence. The very 
distinguished arrangement of Rooms 16, 17 and 18 (position, plan, internal decoration) clearly indicates their representative function, most likely connected to public, social and political activities of the landlord. Another mosaic with black and white tesserae, in a very poor state of preservation, is located in Room 13 (Figure 4a) opening on the eastern ambulatory of the court, while monochrome mosaics with white tesserae are found in Rooms 9 and 28 on the same side of the house. As regards Domus 2a (Figure S2), on the highest terrace of the area, the very limited portion already brought to light shows floor mosaics of the same richness as the contemporary Domus 1 . A polychrome mosaic with a zig-zag pattern and a simple guilloche frame has been partially uncovered in Room 22 (Figure 4b), while Room 28 shows another black and white mosaic (Figure 4c). Additionally, fragments of polychrome and black and white mosaics have also been found in layers related to the collapse of the same house.
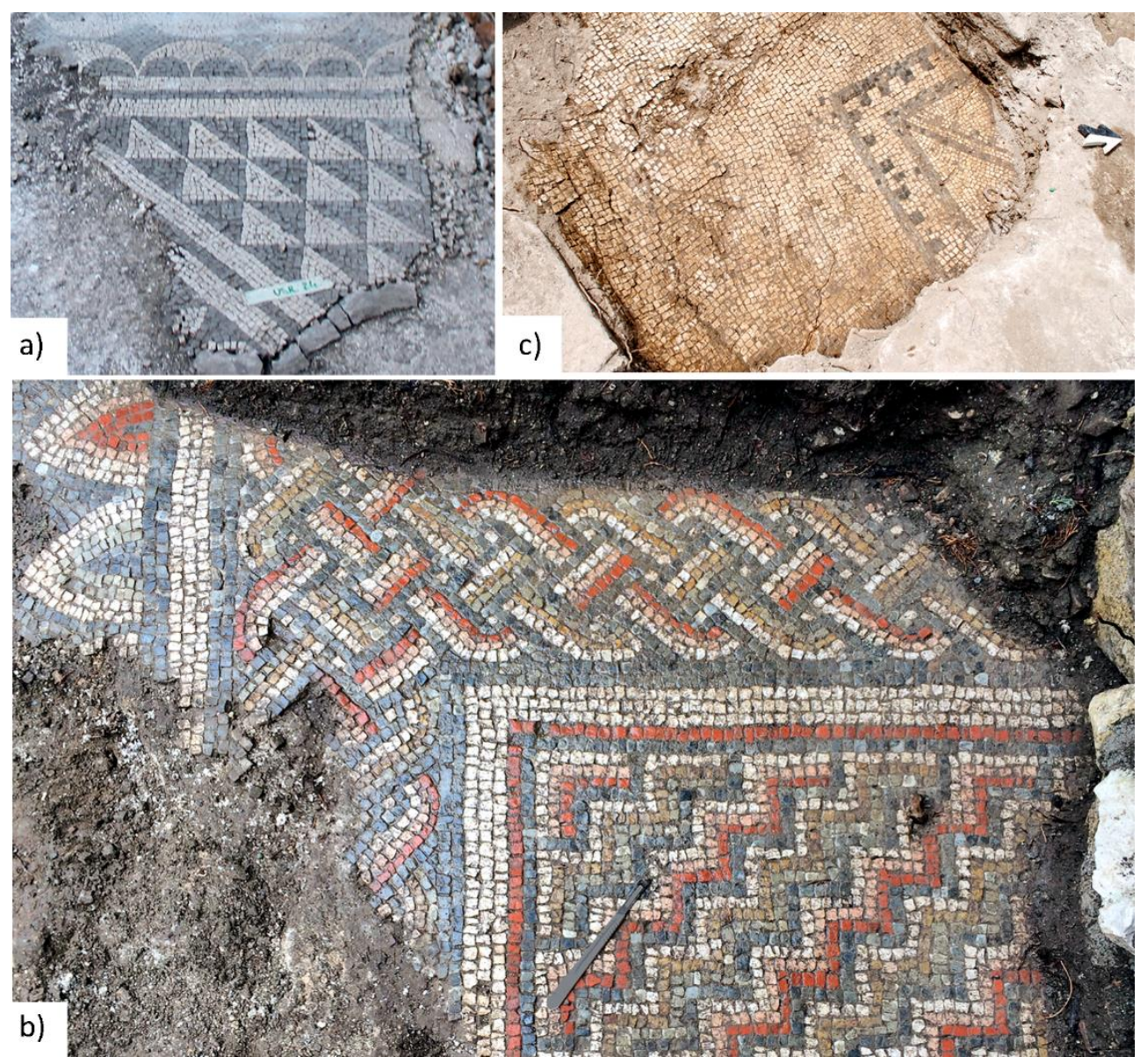

Figure 4. (a) Domus 1, black and white mosaic in Room 13; (b) Domus 2a, polychrome mosaic, partially uncovered, in Room 22; and (c) Domus 2a, black and white mosaic in Room 28.

\section{Materials and Methods}

\subsection{Sampling}

For all the samples, the excavation data ensure that they originally belonged to mosaics of Domus 1 and Domus 2a (no mosaics have been discovered to date in Domus 2). Sampling was carried out by carefully selecting, when possible, already detached tesserae of the most significant areas of each mosaic, also covering the full range of colors. More specifically, a set of 72 stone tesserae ( 37 white, 30 black, 2 pink, 1 red, 1 orange and 1 yellow) was collected from the different mosaics together with 7 glass tesserae ( 3 blue, 1 red and 3 slightly opaque whitish samples) recovered from the niche area of the central room (Room 17) of the southern side of Domus 1. 
The first visual inspection evidenced the good conservation state of the full set of stone samples, since none of the 72 lithic tesserae showed macroscopic deterioration phenomena, i.e., no crusts, efflorescence or significant loss of materials were observed. However, it is worth mentioning that a slight chromatic alteration was detected in some of the black and white samples, where a thin and uniform pale whitish patina was present. The presence of newly formed calcite on carbonate lithic surfaces may be related to the impact of dissolved $\mathrm{CO}_{2}$ and/or to biodeterioration phenomena occurring at the soil-air interphase [45,46]. However, this whitish layer resulted in a macroscopic chromatic alteration, so that in the first samples' cataloging operations some black samples were wrongly classified as pale blue tesserae. Conversely, some of the glass tesserae displayed surface iridescence, clearly indicating the occurrence of macroscopic degradation. Once the samples were collected, they were gently brushed; the lithic tesserae were also washed with demineralized water and dried at $60{ }^{\circ} \mathrm{C}$ for $48 \mathrm{~h}$. All the samples were photographed (Figure 5), stored in zip bags and labeled for being transferred to the laboratory and then left under controlled environmental conditions before analyses.
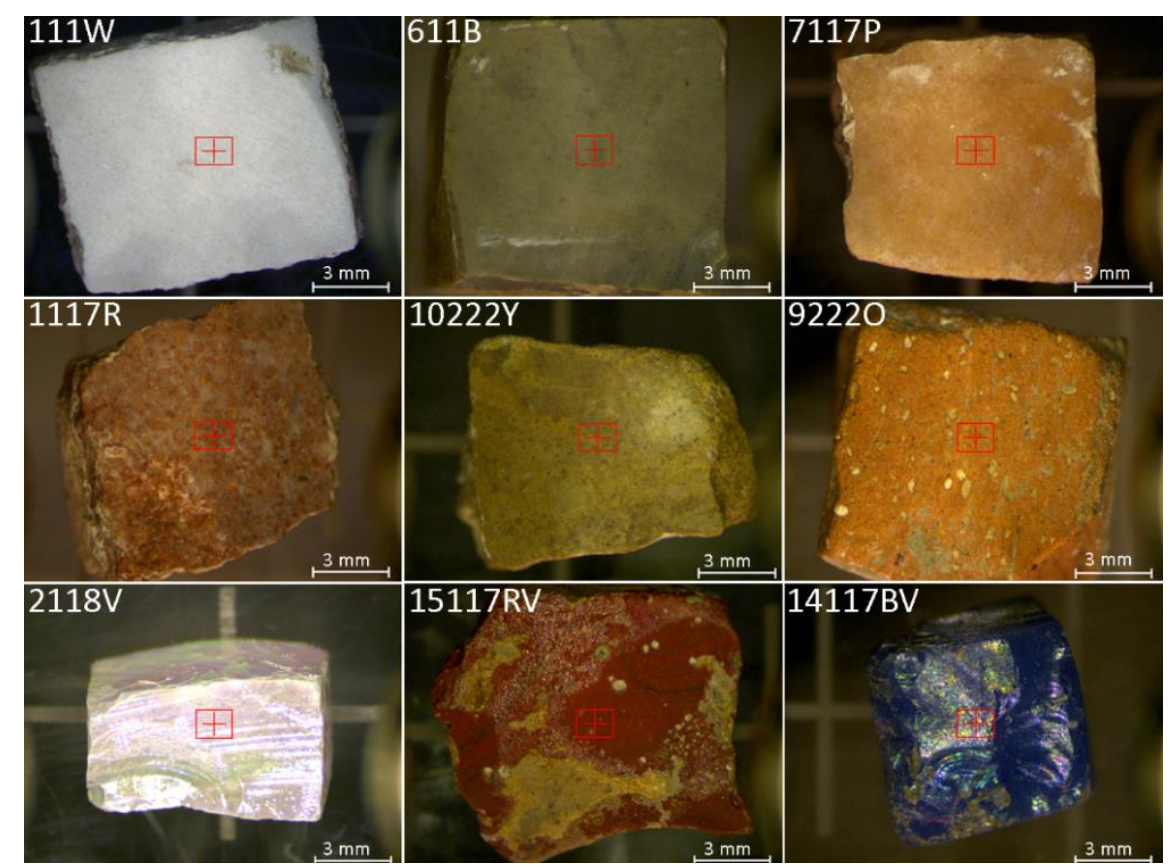

Figure 5. Representative selection of the studied tesserae showing samples' colors and materials.

The nomenclature used indicates $\mathrm{n}^{\circ}$ sample/domus/room/color; in which the final " $\mathrm{V}^{\text {" }}$ has been assigned only for glassy samples (Table S1). No sample treatment was performed prior to carrying out the spectroscopic analysis. Exceptionally, samples with the mentioned pale whitish patina, identified as calcite by Raman spectroscopy, were slightly polished to avoid interferences in the surface analysis. Furthermore, since for a selected small sample set a micro-destructive XRD analysis was required, the Italian guidelines (normal 3/80) [47] of minimally invasive sampling were strictly followed. For this purpose, a scratch with a scalpel and a grind with agate mortar were employed.

\subsection{Instruments}

The dual M4 TORNADO ED-XRF spectrometer (Bruker Nano GmbH, Berlin, Germany) was used to study the elemental composition. The equipment presents two microfocus side window Rh X-ray tubes powered by low-power HV generators and cooled by air. The first tube can work between $10-50 \mathrm{kV}$ and $100-600 \mu \mathrm{A}$ and it is connected to a poly-capillary system that allows it to work under a lateral/spatial resolution of $25 \mu \mathrm{m}$ measured for Mo K $\alpha$ (around $17 \mathrm{~mm}$ at $2.3 \mathrm{keV}$ to $32 \mu \mathrm{m}$ at $18.3 \mathrm{keV}$ ). The second X-ray tube is able to operate at a maximum of $50 \mathrm{kV}$ and $700 \mu \mathrm{A}$, and it is coupled to 
a mechanical collimator that allows X-ray spot sizes of $1 \mathrm{~mm}$. The detection of the fluorescence radiation was performed using a XFlash ${ }^{\circledR}$ silicon drift detector with $30 \mathrm{~mm}^{2}$ of the sensitive area and an energy resolution of $145 \mathrm{eV}$ for Mn-K $\alpha$. For this work, in accordance with the sample size and heterogeneity featuring the major and minor elements composition, the collimator was used for single point analysis of white and colored tesserae whereas the poly-capillary optic was used for the analysis of black samples. In all cases, the live time employed for each single acquisition was $150 \mathrm{~s}$. For most of the elements, the selected line was the K $\alpha 1$, except for Ba for which its corresponding $L \alpha 1$ line was employed. The average composition was calculated from 5 to 10 measurements per sample for the collimator and poly-capillary systems, respectively, and the elemental results were presented in wt.\%. In addition, to improve the detection of the lightest elements $(Z>11)$, the measurements were acquired under a vacuum $(20$ mbar) by means of a diaphragm pump MV 10 N VARIO-B. Data collection and interpretation were carried out by means of the software M4 TORNADO (Bruker Nano $\mathrm{GmbH}$ ), whereas the quantitative analyses were carried out using the deconvolution M-Quant software package based on the application of fundamental parameters quantitative methods, previously validated with analogous lithic standards.

The EDXRF data obtained for the black and white samples were independently submitted to a PCA multivariate analysis after column autoscaling. A data analysis was performed in the Matlab environment (The MathWorks) version 2020a, using the PLSToolbox package (Eigenvector Research). A total of 37 white and 30 black samples were analyzed including a part of the name, two categorical variables, namely Domus (D1 and D2a) and the room of discovery. A total of 21 and 14 continuous variables were determined for white and black samples, respectively.

An inVia confocal Renishaw Raman microscope was used to perform the molecular characterization. The spectrometer is equipped with a Peltier-cooled CCD detector and coupled with a DMLM Leica microscope with a motorized XYZ positioning stage with integrated position sensors on the $\mathrm{X}$ and $\mathrm{Y}$ axes. The measurements were carried out using the $20 \times$ and $50 \times$ objectives together with $785 \mathrm{~nm}, 633 \mathrm{~nm}$ and $514 \mathrm{~nm}$ excitation lasers. A daily instrumental calibration was performed using the band at $520.5 \mathrm{~cm}^{-1}$ of a silicon chip. The Raman spectra were acquired using the Wire 3.0 Renishaw software and the treatment was made using Wire 3.0 and Origin 2017 software. For the data interpretation the e-VISART, e-VISARCH, e-VISNICH and RUFF spectra databases were used [48-51].

In samples showing high fluorescence that hindered the assignation of the Raman spectra, an XRD analysis of the ground samples was performed with a PANalytical X'Pert PRO diffractometer equipped with a copper tube $\left(\lambda C u_{K \alpha}\right.$ mean $=1.5418 \AA, \lambda C u_{K \alpha 1}=1.54060 \AA$ and $\lambda \mathrm{Cu}_{\mathrm{K} \alpha 2}=1.54439 \AA$ ), a vertical goniometer (Bragg-Brentano geometry), programmable divergence aperture, automatic interchange of samples, secondary graphite monochromator and PixCel detector. The operating conditions for the copper tube were $40 \mathrm{KV}$ and $40 \mathrm{~mA}$, with an angular range (20) scanned between $5^{\circ}$ and $70^{\circ}$. The treatment of the diffractograms and the mineral phases' identification were carried out using the specific PANalytical X'Pert HighScore software, in combination with the Power Diffraction File database (PDF-2) from the International Center for Diffraction Data (ICDD) [52], determining the semi-quantitative values as a function of the height of the maximum diffraction peak for each phase identified.

\section{Results and Discussion}

Experimental data are discussed in this section by material typology (natural or artificial, i.e., stone or glass), and then by colors.

\subsection{Stone Tesserae}

\subsubsection{White and Black Tesserae}

The EDXRF average data obtained from the full set of white and black samples are shown in Table S2. 
In detail, a calcareous nature was observed in all white samples by the identification of $\mathrm{Ca}$ as a major element, with values between $96 \mathrm{wt} . \%$ and $99 \mathrm{wt} . \%$, decreasing to $80 \mathrm{wt} . \%$ for tesserae coming from the east ambulatory of Domus 1, namely 11AEW-51AEW, and for the $1222 \mathrm{~W}$ sample only. For these samples, a significant amount of $\mathrm{Mg}$ (i.e., approximately $19 \mathrm{wt} . \%$ ) was found. In addition, all the samples showed the presence of $\mathrm{Sr}, \mathrm{Mn}, \mathrm{P}, \mathrm{Ni}, \mathrm{Zn}$ and $\mathrm{Fe}$ as trace elements. Among them, the presence of strontium should be noted since the found levels seem to be compatible with the lithotypes of the area, suggesting local supplying [53,54]. All the other elements (i.e., $\mathrm{Ti}, \mathrm{Al}, \mathrm{K}, \mathrm{S}$ and $\mathrm{V}$ ) were always randomly present as trace components. In order to find similarities among the samples within the set of white and black tesserae, as well as to relate the samples' composition with their location into the archaeological site, a PCA was performed on white and black samples. The score plot obtained for the white tesserae semi-quantitative EDXRF data was assessed by coloring samples as a function of the room of discovery, where the shape of symbols accounted for the Domus (Figure 6a); sample names are omitted for the sake of clarity. The loading plot of white tesserae data are given in Figure 6b.

a)

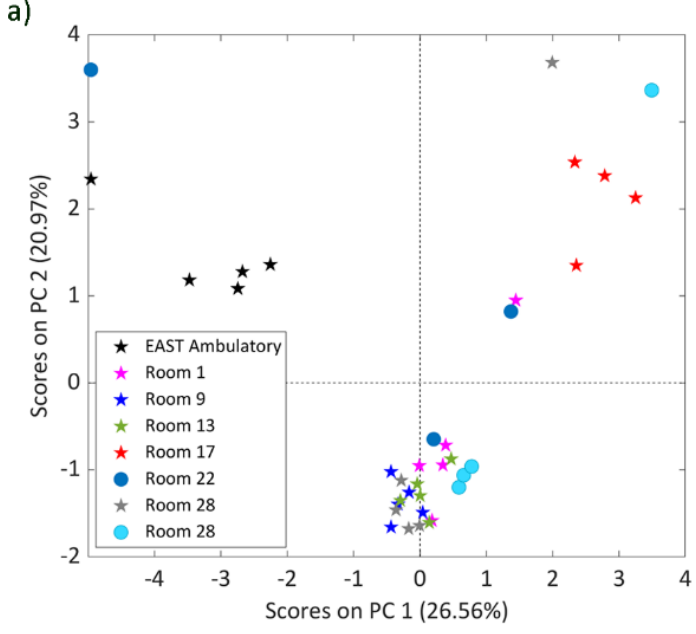

c)

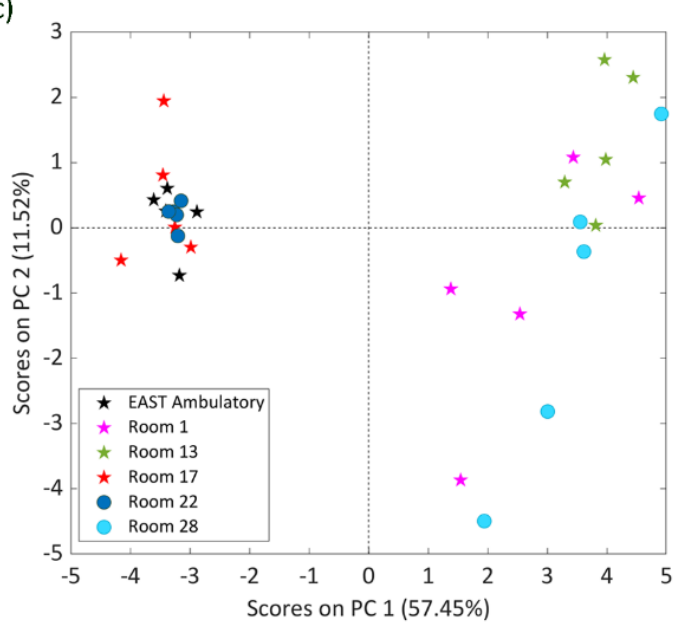

b)

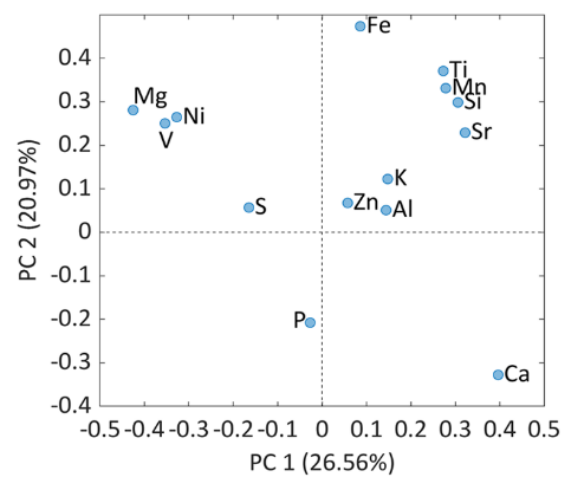

d)

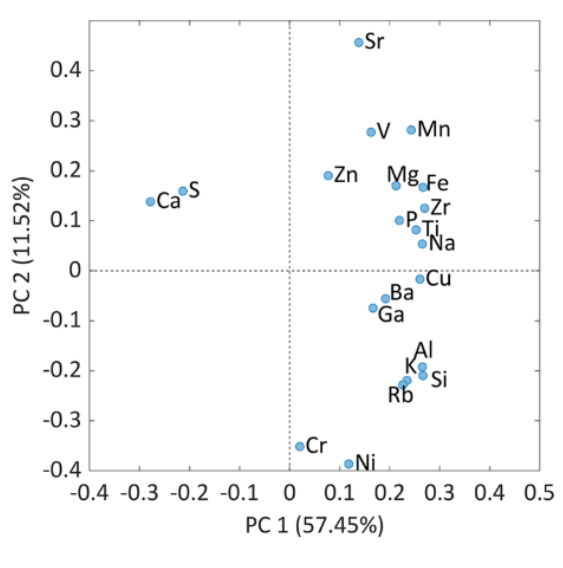

Figure 6. PCA of EDXRF data for white tesserae (a) score; and (b) loading plots in the space of PC1 vs. PC2 for $47.5 \%$ of total variance; and for black tesserae (c) score; and (d) loading plots in the space of PC1 vs. PC2 for $69.0 \%$ of total variance.

Three groups may be evidenced in the score plot: the first featured negative values on PC1 including all east ambulatory (AE) white tesserae and one sample coming from Room 22 (Domus 2a); the second, with positive values on both PC1 and PC2, that includes all samples of Room 17 (Domus 1), one from Room 1 (Domus 1), one from Room 22 (Domus 2a), one from Room 28 (Domus 1) and one from Room 28 (Domus 2a); the third, the most numerous, containing all samples belonging to Room 9 (Domus 1), Room 13 (Domus 1), 
Room 28 (Domus 1, except one), 28 (Domus 2a, except one), Room 1 of Domus 1 (except one) and one sample of Room 22 (Domus 2a). All white samples found in Room 22 showed a different composition, i.e., they did not form any grouping, not allowing any further consideration. Looking at the loading plot (Figure 6b), samples collected in the east ambulatory are characterized by the highest amount of $\mathrm{Mg}$ (negative values for PC1), are relatively rich in $\mathrm{Ni}$ and $\mathrm{V}$ and show low concentrations of elements such as $\mathrm{Ca}$ and $\mathrm{Sr}$ (S in a lower extent), that are related with the positive values of PC1. Accordingly, tesserae from Room 17 are characterized by low concentrations of $\mathrm{Mg}$ as well as relatively high concentrations of $\mathrm{Sr}$ with some other elements such as $\mathrm{Si}, \mathrm{Al}$ or $\mathrm{K}$ and $\mathrm{Fe}$, which are mainly related to PC2. Tesserae from Rooms 1, 9, 13 and 28 form a group where essentially samples made of calcite, characterized by high Ca concentrations, belong. PC1 mainly explains the ratio between $\mathrm{Mg}$ and $\mathrm{Ca}$ and the content of $\mathrm{Sr}$, while PC2 accounts again for the amount of $\mathrm{Ca}$ and for the contribution of trace elements such as Fe, Si and Ti.

It is worth mentioning that samples collected in Rooms 13 and 17 (Domus 1) displayed the same group for both black (see later) and white samples as well as the east ambulatory of the court (Figure S6).

The Raman analysis of the different types of white tesserae provided additional information, allowing us to identify in the first group characterized by a high $\mathrm{Mg}$ content (east ambulatory, see Figure 6b), not only calcite, but a significant presence of dolomite $\left(\mathrm{CaMg}\left(\mathrm{CO}_{3}\right)_{2}\right.$, signals at 177, 301, 725 and $\left.1098 \mathrm{~cm}^{-1}\right)$ and also a displacement of the main calcite band, revealing the presence of significant amounts of magnesium-rich calcite (signal at $1087 \mathrm{~cm}^{-1}$ ). XRD measurements carried out on white samples of this group allowed us to semi-quantify the relative ratio between dolomite and calcite around $88 \%$ and $12 \%$, respectively. These samples showed some occasional grains of pyrite (signals at 343,380 and $431 \mathrm{~cm}^{-1}$ ) as well. On the contrary, in the Raman spectra collected in the second group of white tesserae including samples from Room 17 and characterized by the highest amounts of $\mathrm{Ca}$ (positive side of PC1, see Figure $6 a, b$ ), calcite was identified as the main carbonate phase, although high magnesium calcite was also detected in the $2117 \mathrm{~W}$ sample. The Raman spectra collected on samples belonging to the third group (Rooms 1, 9 13 and 28) showed only calcite, as also confirmed by the XRD measurements.

All the reported findings for magnesium containing white tesserae are compatible with the composition of the typical dolomitic lithotypes of the area, already identified in the materials employed in the mosaic pavements of another Roman house explored in Taormina, in the nearby area of Porta Pasquale $[39,40,55]$. Moreover, the use of magnesium containing material for obtaining the tesserae of the pavement of the Domus 1 east ambulatory could have been not a casual choice, since it could have been perhaps related to the empiric awareness of dolomite resistance against weathering [56]. Figure S6 shows the outdoor location of the east ambulatory, clearly exposed to atmospheric agents like rains. In this light, the employment of low water-soluble materials, in particular at acidic pHs, as is typical of rains closer to volcanic areas, could have been a reasonable option to avoid their possible deterioration. Accordingly, from a chemical point of view, the use of dolomitic material, instead of calcite, should be preferred, since at acidic $\mathrm{pH}(5.7-6.1)$ the solubility product in water of the magnesium-containing carbonate $\left(\mathrm{pK}_{\mathrm{s}}\right.$ range $\left.=16.6-17.8\right)[57,58]$ is almost nine orders of magnitude higher than the one displayed by calcite $\left(\mathrm{pK}_{\mathrm{s}}=8.4-8.5\right)$ [59-61].

Black tesserae displayed a much higher heterogeneous elemental composition. In detail, all the samples taken from Domus 1, Room 17 (8117B-12117B), the ones from the east ambulatory (61AEB-101AEB) and those coming from Domus 2a, Room 22 (4222B-8222B) evidenced a calcareous nature of the Ca amount ranging between $74 \mathrm{wt} . \%$ and $86 \mathrm{wt} \%$. Si was also present as a minor element in significant amounts, between approximately $9 \mathrm{wt} \%$ and 16 wt.\%, followed by $\mathrm{Al}$ and Fe that reached, as their highest values, 3 wt. $\%$ and 2 wt.\%, respectively. $\mathrm{Mn}, \mathrm{Cr}, \mathrm{Ti}, \mathrm{Sr}, \mathrm{S}, \mathrm{Zn}, \mathrm{Mg}$ and $\mathrm{K}$ were mainly found to be trace elements. However, all the other black tesserae were characterized by having $\mathrm{Si}$ as a major element, with percentages of approximately $30 \mathrm{wt} . \%$ and $47 \mathrm{wt} . \%$, and a significant concentration of $\mathrm{Ca}$ and $\mathrm{K}$, depending on the sample. In this set, 611B, 911B, and almost all samples 
collected in Domus 1, Room 13 (i.e., 6113B-8113B and 10113B, as well as 6228B, 8228B and 10228B) were Ca-rich samples with values ranging from $15 \mathrm{wt} . \%$ to $23 \mathrm{wt} . \%$ and also with significant amounts of $\mathrm{K}, \mathrm{Al}, \mathrm{Fe}$ and $\mathrm{Mg}$ in the range of concentrations of $\mathrm{Ca}$ of 8-16 wt.\%, 11-16 wt. \%, 8-13 wt.\% and 1-4 wt.\%, respectively. On the contrary, a K-rich composition was found for $711 \mathrm{~B}, 811 \mathrm{~B}, 1011 \mathrm{~B}, 9113 \mathrm{~B}$ and $9228 \mathrm{~B}$ with potassium concentrations ranging between 16 and 25 wt. \%, followed by $\mathrm{Ca}$ at about $12 \mathrm{wt} . \%, \mathrm{Al}$ at $16 \mathrm{wt} . \%, \mathrm{Fe}$ in the range of 4-11 wt.\% and concentrations close to $2 \mathrm{wt} \%$ for $\mathrm{Mg}$. Na was independently detected in both sets of samples between 1 wt.\% and 3 wt.\%, whereas $\mathrm{Sr}, \mathrm{P}, \mathrm{Mn}, \mathrm{Rb}, \mathrm{Zr}, \mathrm{Ba}, \mathrm{Cu}$, $\mathrm{Zn}$ and Ti were always found as trace elements for all the black samples. The observed elemental compositions, together with the close location of the Etna volcano, allowed the advancement of the hypothesis that some of the black tesserae could have a local volcanic origin $[62,63]$.

The score and loading plots for black tesserae EDXRF data in the space of PC1 vs. PC2 for $69.0 \%$ of the total explained variance are reported (Figure $6 c, d$ ). Looking at Figure $6 c$, sample groupings can be clearly distinguished: the first featured by negative values on PC1, including samples from Room 17, 22 and the east ambulatory (AE) of Domus 1; the second with samples coming from Rooms 1 and 13 from Domus 1, and Room 28 from Domus 2a. The loading plot clearly shows that PC1 was related to the main nature of the material, displaying $\mathrm{Ca}$ and $\mathrm{Si}$ at opposite values (negative correlation, as observed above for $\mathrm{Ca}$ and $\mathrm{Mg}$ in the case of white samples), thus accounting for black carbonate stones on the negative side and black stones of probable volcanic origin on the positive side of PC1 of the score plot in Figure 6c. Among the non-carbonate samples, samples from Room 13 were characterized by the highest amounts of strontium and lowest amounts of K, which were the main elements explained by PC2. Furthermore, samples belonging to Room 28 (Domus 2a) and Room 1 (Domus 1) showed a heterogeneous composition regarding PC2. It is worth mentioning that according to the XRF database of Italian volcanic stones [64], high potassium volcanic lithotypes are typically quite common in central Italy (i.e., Vesuvius and other volcanoes from the Mediterranean area) or in the Eolian Islands, especially near Stromboli, and not in the volcanic area in nearby Taormina, i.e., from Etna. Looking at the contribution of potassium to PC2, samples from Room 13 were characterized by low concentrations of this element and appeared, at first sight, to be compatible with the composition of Etna volcanic stones, whereas some tesserae from Room 28 of Domus $2 \mathrm{a}$ and Room 1 could be imported.

All the collected data suggested the employment of two types of volcanic rocks with different origins. Another hypothesis could be advanced to explain such results, assuming the use of a single kind of volcanic stone suffering two different weathering phenomena, since aluminosilicates can be hydrolyzed, in slightly acidic $\mathrm{pH}$ conditions, and be lost by dissolution [16]. However, this hypothesis was discarded as both kinds of volcanic stones were found, in various cases, inside the same room (i.e., Room 28 in Domus 2a and Room 1 in Domus 1; Figure S6), so that neither a different environmental exposure of the same kind of stone (i.e., indoor and outdoor) nor the activities carried out inside the rooms could be invoked to explain such an argument.

Raman analyses corroborated the elemental investigations, providing additional compositional information of each typology of black tesserae. In detail, the spectra collected on samples belonging to the first group (Figure 7) characterized by high Ca concentrations, evidenced the presence of calcite $\left(\mathrm{CaCO}_{3}\right.$, signals at 154, 281, 712 and $\left.1085 \mathrm{~cm}^{-1}\right)$ as the major compound, and also detected, as a minor phase, high magnesium calcite $\left(\mathrm{Ca}_{\mathrm{x}} \mathrm{Mg}_{1-\mathrm{x}} \mathrm{CO}_{3}\right.$, main signal at $\left.1088 \mathrm{~cm}^{-1}\right)$. Silicon was mainly identified as quartz $\left(\alpha-\mathrm{SiO}_{2}\right.$, by a main Raman peak at $464 \mathrm{~cm}^{-1}$ ). Amorphous charcoal was commonly detected (characteristic double band at $\left.1325-1600 \mathrm{~cm}^{-1}\right)$ and, in very few cases, gypsum was found $\left(\mathrm{CaSO}_{4} \cdot 2 \mathrm{H}_{2} \mathrm{O}\right.$, signals at 414, 493, 619, 670, 1008 and $1135 \mathrm{~cm}^{-1}$ ); this was very likely the only degradation compound formed by an acid attack on the original carbonatic matrix [15], which also helps in the explanation of the closeness of Ca and S in Figure 6d. Finally, iron was mainly 
found as hematite $\left(\alpha-\mathrm{Fe}_{2} \mathrm{O}_{3}\right.$, characterized by signals at $660,615,409,290$ and $\left.226 \mathrm{~cm}^{-1}\right)$ and, sporadically, as pyrite $\left(\mathrm{FeS}_{2}\right.$, signals at 339 and $\left.373 \mathrm{~cm}^{-1}\right)$.

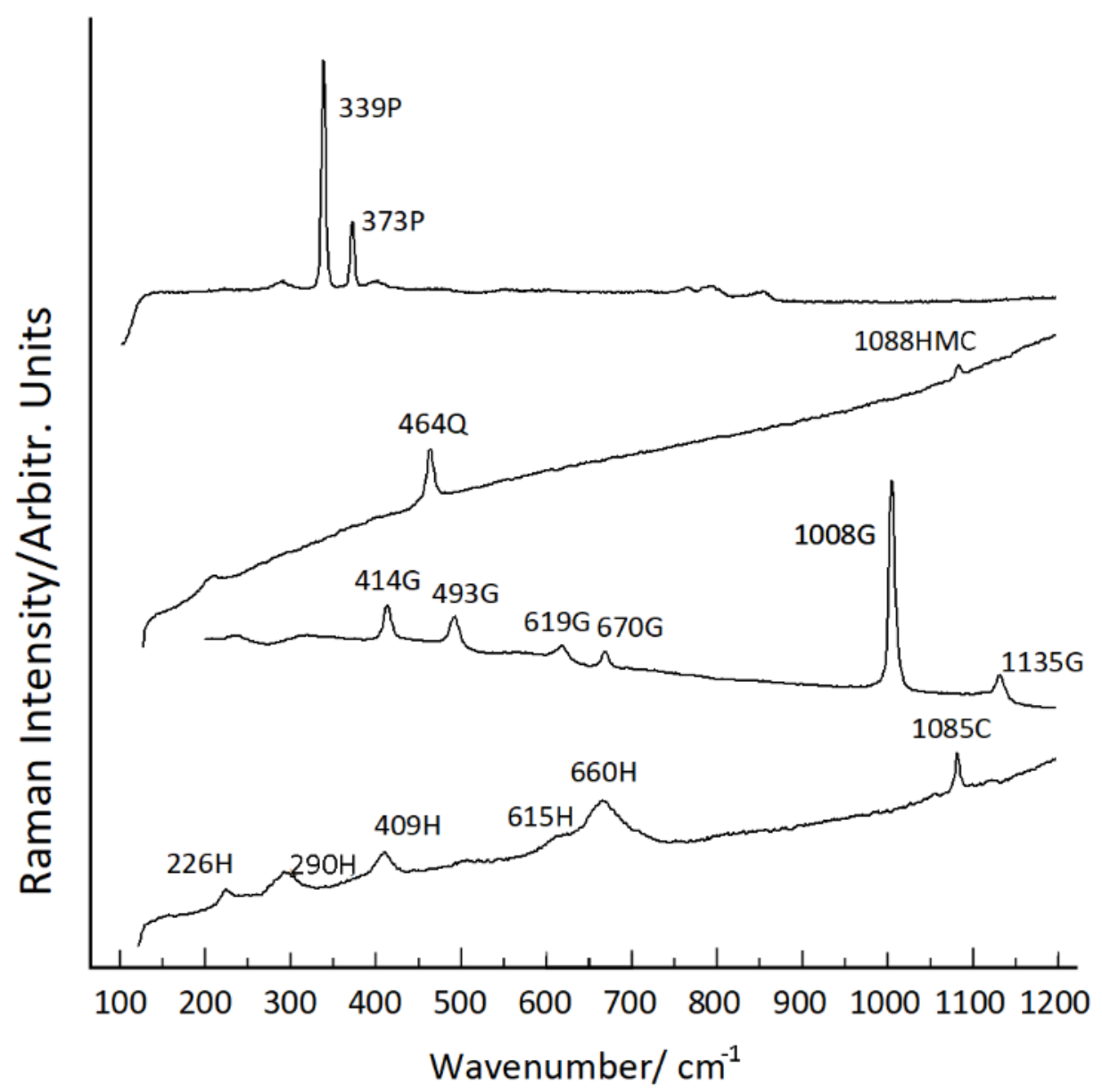

Figure 7. Raman spectra collected on carbonatic black samples, in which high magnesium calcite $(\mathrm{HMC})$, quartz $(\mathrm{Q})$, hematite $(\mathrm{H})$, pyrite $(\mathrm{P})$ and gypsum $(\mathrm{G})$ signals are identified.

In order to further ascertain the type and/or amount of aluminosilicates present in the black tesserae of carbonate nature, XRD measurements were performed on selected samples. On this sample set, a percentage of aluminosilicate between 5 and $10 \%$ was found, with the relative proportion between calcite and quartz being approximately $84 \%$ and $16 \%$, respectively. Therefore, all the findings suggested that the black tesserae belonging to the first group could correspond to the local typical deep grey/black marly limestone [65-69].

The Raman spectra collected on volcanic tesserae showing high-K content (Figure 8) (samples from Rooms 1 and 28, see Figure 6c,d) often showed the iron in the form of hematite. Moreover, pyrite was not found in these samples, in agreement with the PC1 vs. PC2 representation, where $\mathrm{S}$ was negatively correlated with Fe. On the contrary, quartz (signal at $\left.465 \mathrm{~cm}^{-1}\right)$ and even apatite $\left(\mathrm{Ca}_{5}\left(\mathrm{PO}_{4}\right)_{3}(\mathrm{~F}, \mathrm{Cl}, \mathrm{OH})\right.$, signals at $428,445,580,589$, $605,614,963,1033$ and $1058 \mathrm{~cm}^{-1}$ ) were also identified in this type of sample, in agreement with the concentration values of $\mathrm{Si}$ and $\mathrm{P}$ observed in the samples. In addition, different compounds of magmatic origin such as leucite $\left(\mathrm{KAlSi}_{2} \mathrm{O}_{6}\right.$, signals at 149, 183, 497 and $\left.529 \mathrm{~cm}^{-1}\right)$, unoriented nepheline $\left((\mathrm{Na}, \mathrm{K}) \mathrm{AlSiO}_{4}\right.$, signals at a 203, 267, 352, 398, 464, 995 and $\left.1086 \mathrm{~cm}^{-1}\right)$ and calcium diopside $\left(\mathrm{CaMgSi}_{2} \mathrm{O}_{6}\right.$, signals at 137, 319, 350, 386, 664, 853 and $1011 \mathrm{~cm}^{-1}$ ) were frequently found. The detection of leucite in the high-K samples also explains both the high amount of $\mathrm{K}$ and the correlation among $\mathrm{K}, \mathrm{Al}$ and $\mathrm{Si}$ in the loading plot (Figure 6d) of black tesserae. 


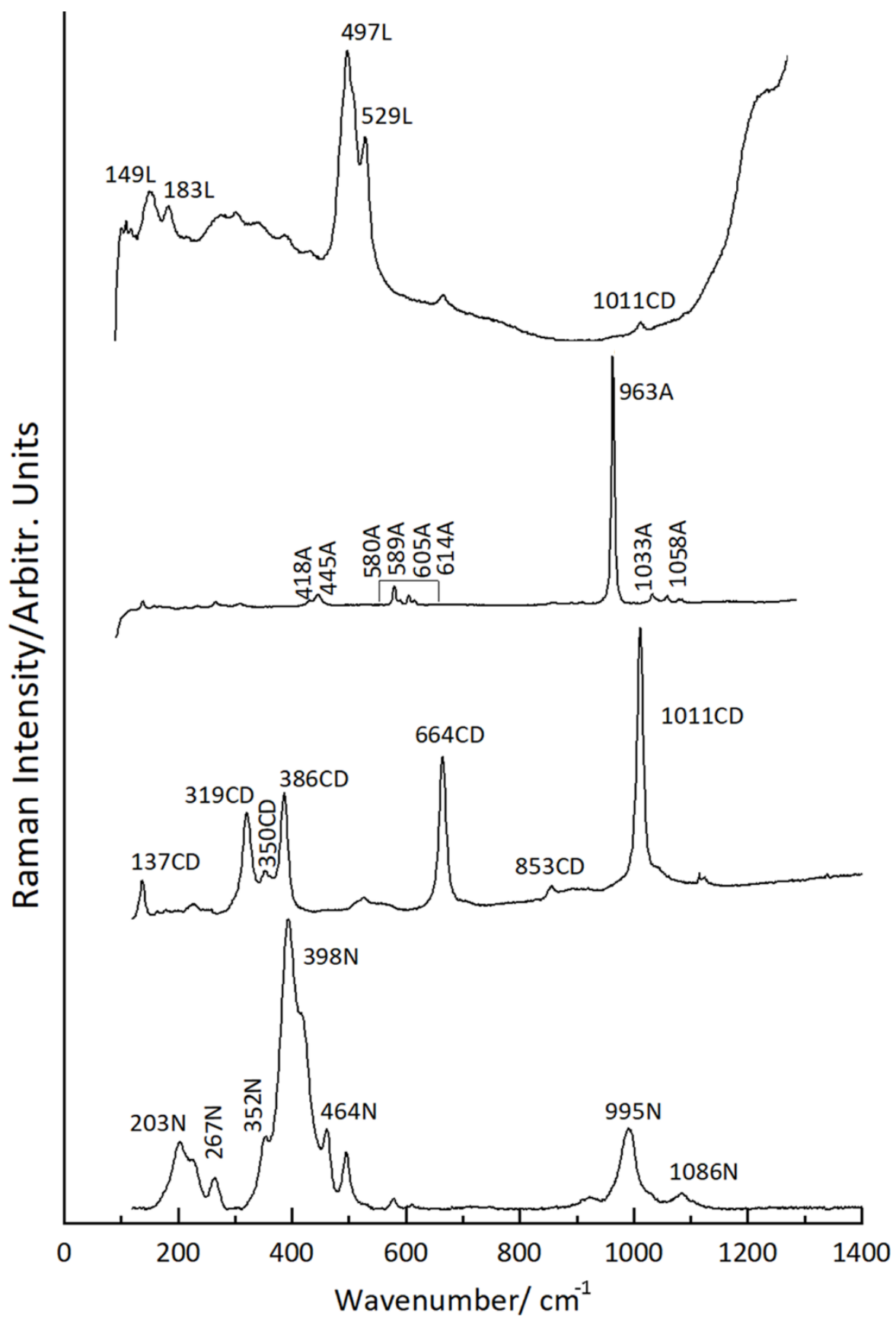

Figure 8. Raman spectra collected on volcanic black samples, in which apatite (A), leucite (L), unoriented nepheline $(\mathrm{N})$ and calcium diopside $(\mathrm{CD})$ are identified.

The XRD analysis fully supported and extended the spectroscopic findings by the identification of anorthite, norsethite $\left(\mathrm{CaMg}\left(\mathrm{CO}_{3}\right)_{2}\right)$, augite $\left(\mathrm{Ca}(\mathrm{Fe}, \mathrm{Mg}) \mathrm{Si}_{2} \mathrm{O}_{6}\right)$, leucite, nepheline and pyroxene family compounds, probably in the form of diopside (Figure 9). In addition, as is common for volcanic materials, significant amounts of amorphous phases (volcanic glass) were found. Volcanic compounds were identified in the group of low-K volcanic tesserae; that is, samples from Room 13. For these tesserae, anorthite $\left(\mathrm{CaAl}_{2} \mathrm{Si}_{2} \mathrm{O}_{8}\right.$, main signals at 483,505 and $559 \mathrm{~cm}^{-1}$ ) was commonly found and, as expected considering the concentrations detected by XRF for $\mathrm{Si}$ and $\mathrm{Al}$, in this case, quartz and leucite were neither identified by XRD nor by any of the other techniques employed. An accurate literature analysis on Italian volcanic rocks data confirmed that the black K-rich samples composition [70] was compatible with the ones displayed by some effusive volcanic rocks 
found in the northern Lazio area (Albani hills, Ernici, Sabatini mounts) and Stromboli Island [64] featured by three main mineralogical phases namely leucite, augite or diopside and nepheline. However, low-K black tesserae displayed anorthite as a significant component, which is typical of Taormina and Etna areas' geochemistry [62,71], and quartz as an accessory phase.

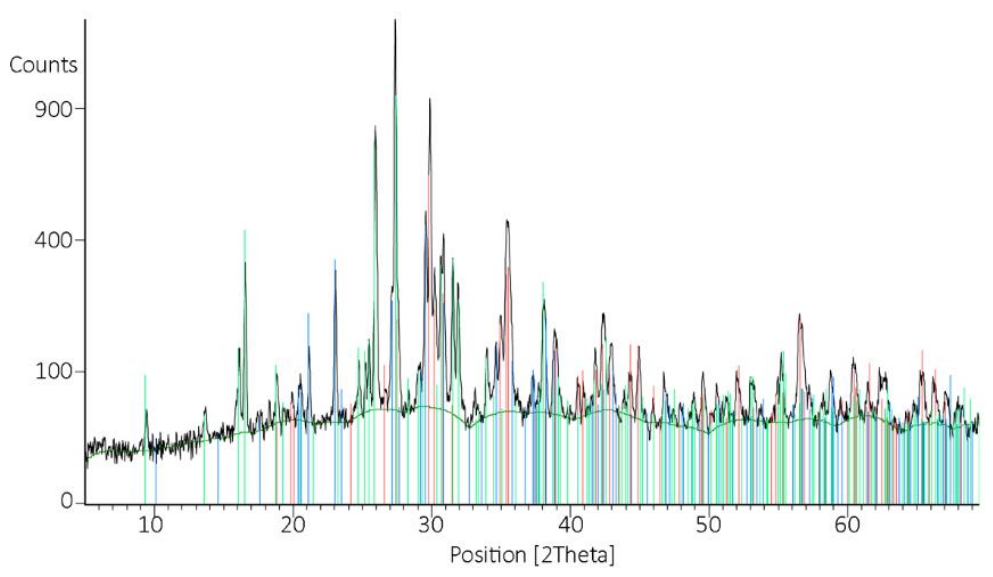

Figure 9. X-ray diffraction results from sample 9113B. The diffraction maxima allow the following crystalline phases to be identified: leucite (L) (green), nepheline (N) (blue) and diopside (D) (red) from the group of pyroxenes, in $42 \%, 26 \%$ and $32 \%$, respectively. In volcanic materials the presence of significant amounts of amorphous phases (volcanic glass) means that the semi-quantitative values found for crystalline phases account only for their relative proportions.

This evidence also contributes to discarding the mentioned hypothesis of the employment of a single kind of volcanic stone involved in different weathering phenomena, suggesting instead the supplying of raw materials of different origins to obtain the black tesserae that, as shown by the archaeometric findings, could be explained in various ways. It should be premised that in most cases tesserae were made directly on the site by the workers in charge of creating the mosaics, by cutting larger pieces of stone, which could have come either from local quarries or been imported; on the contrary, evidence regarding workshops specifically devoted to the processing of tesserae is scarce [1].

Therefore, the hypothesis that ready-made tesserae were imported to Taormina from other centers seems unlikely. Moreover, the theory that on the site there was a group of nonlocal workers, who had brought raw materials from their place of origin can be discarded since the homogeneous stylistic characteristics of all the mosaics of the domus would lead to the exclusion that they were made by different workshops (local and non-local). It seems more plausible to hypothesize that non-local volcanic stones were already present in Taormina as building material or for some other purpose and that, once dismissed, they were purchased and reused for obtaining tesserae on the working site. Alternatively, it could be assumed that a batch of non-local volcanic stones was directly purchased from the market either for reasons of economic convenience or because it was considered preferable to the local one for technical reasons (better workability) or for higher aesthetic qualities; about this, it should be taken into account that the choice of different materials could be related to the higher or lower importance of the rooms (i.e., to their private or representative functions). All the data found about the black and white samples open new questions and raise several issues about the origin or the specific choice of precise lithotypes for tesserae production, and clearly indicate that further in situ investigations are indeed required to clarify the proposed hypotheses.

\subsubsection{Pink and Red Tesserae}

The EDXRF measurements carried out on pink 7117P and 11222P tesserae (Figure 5) evidenced a calcareous nature with $\mathrm{Ca}$ and $\mathrm{Mg}$ percentages of around $80 \mathrm{wt} . \%$ and $18 \mathrm{wt} . \%$, respectively, and trace elements content related to the presence of $\mathrm{Fe}, \mathrm{Sr}$ and $\mathrm{Al}$. In addition, 
Raman spectra collected for 7117P and 11222P revealed the presence of dolomite (signals at 177, 300, 725 and $1097 \mathrm{~cm}^{-1}$ ), calcite and hematite. XRD data fully supported the spectroscopic findings with a relative ratio of dolomite and calcite of around $88 \%$ and $12 \%$. This composition matched the one observed for white samples located in the east ambulatory of Domus 1, suggesting the use of similar local limestones. The difference of lithotypes' color could be related to the trace presence of Fe, as found in 7117P and $11222 \mathrm{P}$, which is usually related to pink and red hues [72] (Table 1). This can be further observed looking at the elemental compositions of pink samples and 1117R (Room 17, polychrome mosaic Figure 3). Accordingly, the red tessera featured a major amount of $\mathrm{Ca}(88 \mathrm{wt} . \%)$, and the absence of $\mathrm{Mg}$, which were the main differences related also to a $10 \mathrm{wt} . \%$ content of Si and to higher levels of Fe traces, with respect to the pink ones (1 wt.\% vs. $0.2 \mathrm{wt} . \%)$. Raman investigations on red tessera allowed us to identify calcite, quartz, hematite and magnetite $\left(\mathrm{Fe}_{3} \mathrm{O}_{4}\right.$, signal at $\left.670 \mathrm{~cm}^{-1}\right)$. The XRD measurements confirmed the spectroscopic findings, providing also an estimative relative ratio between calcite and quartz in 1117R (i.e., 79\% and 21\%). The color difference between pink and red tesserae could be related to hematite, which was actually detected in both kinds of tesserae by Raman, but its identification and estimation by XRD, known to be quite difficult, was not possible in the collected diffractograms. The whole of the collected data suggested that the pink and red tesserae investigated were made of the local "Rosso San Marco" limestone, also employed in the famous Roman Theater of Taormina [73-75].

Table 1. EDXRF elemental data (wt.\%) of colored stone tesserae samples.

\begin{tabular}{|c|c|c|c|c|c|c|c|c|c|c|c|c|c|c|c|c|}
\hline Sample ID & Si & $\mathrm{Ti}$ & Al & $\mathrm{Fe}$ & Mn & Mg & $\mathrm{Ca}$ & $\mathrm{K}$ & $\mathbf{P}$ & $\mathrm{Cr}$ & $\mathbf{N i}$ & $\mathbf{R b}$ & $\mathrm{Sr}$ & $\mathrm{Zr}$ & V & $\mathrm{Zn}$ \\
\hline $7117 \mathrm{P}$ & N.D. & N.D. & 0.13 & 0.24 & 0.02 & 17.48 & 81.82 & 0.03 & 0.05 & N.D. & N.D. & N.D. & 0.20 & 0.02 & N.D. & 0.01 \\
\hline $1117 R$ & 10.25 & 0.05 & 0.04 & 0.98 & 0.01 & N.D. & 88.47 & 0.01 & 0.05 & N.D. & N.D. & N.D. & 0.13 & 0.01 & N.D. & N.D. \\
\hline $11,222 \mathrm{P}$ & N.D. & N.D. & 0.01 & 0.29 & N.D. & 19.71 & 79.65 & N.D. & 0.04 & N.D. & 0.02 & N.D. & 0.18 & N.D. & N.D. & 0.01 \\
\hline $9222 \mathrm{O}$ & 43.97 & 1.339 & 12.56 & 17.22 & 0.09 & 3.05 & 16.63 & 4.28 & N.D. & 0.03 & 0.01 & 0.11 & 0.27 & 0.32 & 0.05 & 0.06 \\
\hline $10,222 Y$ & 19.76 & 0.57 & 0.38 & 1.66 & 0.04 & 1.71 & 75.16 & 0.25 & 0.24 & N.D. & 0.01 & N.D. & 0.07 & 0.04 & 0.04 & 0.03 \\
\hline
\end{tabular}

\subsubsection{Orange and Yellow Tesserae}

The elemental composition of the $9222 \mathrm{O}$ sample (Figures 4 and 5, Table 1 ) revealed a high content of $\mathrm{Si}(44 \mathrm{wt} . \%)$, followed by $\mathrm{Fe}, \mathrm{Ca}, \mathrm{Al}, \mathrm{K}$ and $\mathrm{Mg}$ that reached concentrations of 17 wt. $\%, 16$ wt. $\%, 12$ wt. $\%, 4$ wt. $\%$ and 3 wt. $\%$, respectively. Ti, Sr and Mn were identified as trace elements. These values clearly correspond to a ceramic matrix composition, where the high iron amount could account for the intense orange color [76]. Raman investigations confirmed that iron was mainly present in the form of hematite (signals at 214, 293 and $\left.411 \mathrm{~cm}^{-1}\right)$ and silicon as quartz $\left(129,207,265,356,394,465,696\right.$ and $\left.1163 \mathrm{~cm}^{-1}\right)$, whereas silicates/aluminosilicates were detected by the identification of forsterite $\left(\mathrm{Mg}_{2} \mathrm{SiO}_{4}, 301\right.$, 545, 825, 856, 880, 921 and $\left.965 \mathrm{~cm}^{-1}\right)$, calcium diopside $\left(319,386,664\right.$ and $\left.1012 \mathrm{~cm}^{-1}\right)$ and augite $\left((\mathrm{Ca}, \mathrm{Mg}, \mathrm{Fe})_{2}(\mathrm{Si}, \mathrm{Al})_{2} \mathrm{O}_{6}, 359,393,667,855,1013 \mathrm{~cm}^{-1}\right)$. Frequently, calcite, high magnesium calcite and charcoal were also identified. XRD investigations detected quartz as the dominant crystalline phase together with, although to a lesser extent, calcite, hematite, feldspars of the plagioclase group as albite $\left(\mathrm{NaAlSi}_{3} \mathrm{O}_{8}\right)$, diopside from the pyroxenes group, possibly spinel $\left(\mathrm{MgAl}_{2} \mathrm{O}_{4}\right)$ and high amounts of amorphous material. All the collected data, considering the combination of both crystalline phases together with glassy material, confirmed that this sample could be a small piece of a brick, made, very likely, by firing dolomitic clays. It is worth mentioning that the calcium diopside formation in ceramics is gained by reaching a heating temperature of, at least, $900{ }^{\circ} \mathrm{C}$, starting from magnesium containing clays [76].

On the other hand, the yellow 10,222Y tessera (Figures 4 and 5, Table 1) seemed to correspond to a carbonate stone since calcium was identified as the main element, with a percentage of $75 \mathrm{wt} . \%$, followed by $\mathrm{Si}, \mathrm{Mg}$ and iron that reached concentrations of $20 \mathrm{wt} . \%$, 2 wt. $\%$ and 2 wt. \%, respectively. In addition, Ti, Al, Mn, K, P, Ni, Sr, Zr, V and Zn were 
detected as trace elements, with contents lower than $1 \mathrm{wt} . \%$. Raman spectra evidenced a composition compatible with the already mentioned local dolomitic materials by calcite (signals at 157, 283, 712 and $\left.1085 \mathrm{~cm}^{-1}\right)$, dolomite $\left(175,298,724\right.$ and $1096 \mathrm{~cm}^{-1}$ ) and quartz $\left(129,207,265,356,394\right.$ and $\left.465 \mathrm{~cm}^{-1}\right)$.

\subsection{Glass Tesserae}

\subsubsection{Semi-Opaque Tesserae}

Samples $16117 \mathrm{~V}, 1118 \mathrm{~V}$ and $2118 \mathrm{~V}$ were slightly whitish glass pieces; among them, $2118 \mathrm{~V}$ was the only one featured by the presence of a thin, fragile and iridescent surface layer (Figure 5, Table 2), known to be indicative of glass degradation [77]. The elemental composition of such samples evidenced high amounts of silicon, calcium and aluminum, i.e., $72 \mathrm{wt} . \%, 12 \mathrm{wt} \% \%$ and between 6-10 wt.\%, respectively. In addition, Sb, approximately 3 wt. $\%$, Fe, ca. 1 wt. $\%, \mathrm{~K}$, between 1-2 wt. \% and $\mathrm{Na}$, ca. 1 wt. $\%$, were identified as minor elements, together with $\mathrm{Ti}, \mathrm{Mn}, \mathrm{Sr}$ and $\mathrm{Pb}$ with concentrations lower than $0.6 \mathrm{wt} . \%$.

Table 2. EDXRF elemental data (wt.\%) of glass tesserae samples.

\begin{tabular}{cccccccccccccccccc}
\hline Sample ID & $\mathbf{S i}$ & $\mathbf{T i}$ & $\mathbf{A l}$ & $\mathbf{F e}$ & $\mathbf{S}$ & $\mathbf{M n}$ & $\mathbf{C a}$ & $\mathbf{N a}$ & $\mathbf{M g}$ & $\mathbf{K}$ & $\mathbf{S r}$ & $\mathbf{C u}$ & $\mathbf{Z n}$ & $\mathbf{C o}$ & $\mathbf{S b}$ & $\mathbf{P b}$ & $\mathbf{S n}$ \\
\hline 16117V & 72.49 & 0.20 & 5.88 & 1.39 & N.D. 0.61 & 12.73 & 1.14 & N.D. 2.05 & 0.23 & 0.01 & 0.02 & N.D. 3.13 & 0.09 & N.D. \\
1118V & 71.67 & 0.15 & 9.28 & 1.32 & N.D. 0.30 & 11.49 & 1.29 & N.D. 1.18 & 0.23 & 0.01 & 0.02 & N.D. 2.93 & 0.10 & N.D. \\
2118V & 71.15 & 0.17 & 9.91 & 1.37 & N.D. 0.32 & 11.57 & 0.76 & N.D. 1.19 & 0.20 & 0.01 & 0.02 & N.D. 3.25 & 0.07 & N.D. \\
14,117BV & 55.41 & 0.10 & 1.76 & 1.82 & N.D. 0.62 & 13.82 & 12.25 & N.D. 0.85 & 0.23 & 0.38 & N.D. & 0.10 & 12.51 & 0.07 & N.D. \\
17,117BV & 60.80 & 0.23 & 7.54 & 2.80 & 0.29 & 0.62 & 10.99 & 4.27 & 0.30 & 3.54 & 0.22 & 0.60 & 0.03 & 0.16 & 6.72 & 0.87 & N.D. \\
18,117BV & 57.51 & 0.17 & 3.22 & 2.38 & 0.47 & 1.11 & 13.96 & 10.38 & 0.15 & 1.75 & 0.20 & 0.44 & 0.01 & 0.24 & 6.53 & 1.43 & N.D. \\
15,117RV & 34.32 & 0.14 & 1.17 & 5.49 & N.D. 0.18 & 6.75 & 14.26 & N.D. 1.40 & 0.12 & 4.05 & 0.04 & N.D. 2.17 & 29.33 & 0.47 \\
\hline \multicolumn{1}{c}{ N.D.: Non-detected. } & & & &
\end{tabular}

It is well established that silica-soda-lime Roman glasses are characterized by high levels of sodium, with average amounts of ca. 15-17\%. Conversely, the data here collected, evidencing much lower levels of sodium and slightly higher concentrations of Si and Al, can be explained in terms of the typical degradation of archaeological glasses, i.e., the leaching of alkali due to the prolonged contact with soil which produces a surface hydrated, alkalidepleted layer, together with the dissolution of the glass matrix [78,79]. In order to further confirm this hypothesis, the sample $2118 \mathrm{~V}$ was gently brushed to eliminate the iridescent patina, then analyzed again by EDXRF. The level of sodium was ascertained by a comparison of the data collected on the surface and on the inner strata of the sample, showing uniform concentration in the whole piece. Even assuming the use of different fluxing agents instead of natron in the original glassmaking, the whole of the collected data on this set of samples seemed rather to indicate that the investigated tesserae were compromised by degradation. It is in fact well established that, in glassmaking, fluxing agents were required to significantly reduce the melting point of quartz; for this purpose, alkali oxides were the most used in antiquity, although in some cases lead oxide ( $\mathrm{PbO})$ was employed as well [80]. From a historical point of view, the replacement of the traditional soda in glassmaking technology is known to have started from the Late Roman/Byzantine Period onwards and was mainly based on the use of plant ash as alkaline flux instead of natron [81]. However, even if the content of lead found here could be explained considering that $\mathrm{PbO}$ was also used as a "stabilizer", the elemental data collected did not allow us to confirm the hypothesis of glassmaking based on the use of plant ashes since they are usually associated to high levels of $\mathrm{K}$ and/or $\mathrm{Mg}$ [82]. In addition, since low $\mathrm{Pb}$ concentrations are said to indicate that the glass was made from primary raw materials, whereas it was observed that the use of cullet or the recycling of glass would impart unusual high $\mathrm{Pb}$ concentrations, the hypothesis of possible recycling should be more deeply investigated [83,84]. In fact, the glass composition deterioration resulting in the loss of sodium fluxes, as the glass is reheated for its reuse, has been observed [85]. Moreover, as a possible explanation of the low sodium content in well preserved tesserae, some authors suggested not only the use of glass waste but also the selection of poorly colored siliceous sands [86]. However, the high amounts of Ca found 
are in agreement with a glass technology based on the use of natron as flux, and lime as stabilizer, also suggesting the use of calcareous sands, containing feldspar as impurities (i.e., $\mathrm{Al}, \mathrm{Ti}, \mathrm{Fe}$ and $\mathrm{Mn}$ ) [81,87]. Another peculiarity of the investigated samples relied on the $\mathrm{Sr}$ concentrations which were found to be approximately $0.2 \mathrm{wt}$.\%. Usually the presence of $\mathrm{Sr}$ is related to the characteristics of the sand employed for glassmaking.

More specifically, beach sands with alkali feldspar as impurities and naturally occurring shell fragments in Mediterranean coastal sands could be the explanation for such a result $[81,88,89]$. Yet, several studies dealing with the analyses of ancient glasses sampled from various Italian areas, such as some Sicilian cities located close to the Etna volcano [90], Lentini and Siracusa in the Iblei mountains area [91], the Ustica volcanic Island [92], Roccamonfina and Somma-Vesuvius in Campania, Sabatini and Alban Hill in the magmatic area near Rome [93], pointed out that volcanic rock fragments could contribute to the formation of Sr-rich sands. Moreover, an intentional addition of the crushed shells introduced as a source of lime could provide high Sr concentrations in glass [94]. The elemental findings also indicated that the opaque white color of the tesserae bulk matrix could be due to the specific use of antimony compounds as opacifying agents, known to have been introduced in glassmaking starting from about 1500 BC up to the end of the Roman period $[80,95,96]$.

Raman spectra collected on this set of samples evidenced the presence of calcite (signals at 155, 281, 713 and $1086 \mathrm{~cm}^{-1}$ ) and quartz (signal at $461 \mathrm{~cm}^{-1}$ ), as well as alkali sulphate (signal at $\left.995 \mathrm{~cm}^{-1}\right)$ and weddellite $\left(\mathrm{CaC}_{2} \mathrm{O}_{4} \cdot \mathrm{H}_{2} \mathrm{O}\right.$, signal at 505, 910, 1050 and $1476 \mathrm{~cm}^{-1}$ ), being the latter two degradation products of glass, for which a leaching of alkali process [80] and a biological origin, respectively, are often assumed [97,98]. As stated, the whole of the collected data on this set of samples seemed to indicate that the investigated tesserae can be originally referred to as Roman "natron" glass technology.

\subsubsection{Blue Glass Tesserae}

14117BV, 17117BV and 18117BV samples (Figure 5, Table 2) are blue glass tesserae found in a secondary context close to the niche of the rear wall, so that it is very likely that they belonged to the mosaic decoration of the niche itself (Table 1, Figure 3). Among them, the surface of $17117 \mathrm{BV}$ is the only one characterized by small spherical holes and iridescent areas strongly suggesting glass degradation processes [77,99]. The EDXRF analysis evidenced high amounts of silicon, between 55-61 wt.\%, followed by significant concentrations of calcium, sodium, antimony and aluminum, i.e., between 11-14 wt.\%, 4-12 wt.\%, 6-12 wt.\% and 2-7 wt.\%, respectively. In addition, $\mathrm{K}$ and Fe, between 1-3 wt.\% and 2-3 wt.\%, respectively, were identified as minor elements, followed by $\mathrm{Ti}, \mathrm{Mn}, \mathrm{Mg}, \mathrm{Cu}$, $\mathrm{Pb}, \mathrm{Mn}$ and $\mathrm{Co}$ with concentrations lower than 0.9 wt.\%. As for whitish tesserae, Sr concentrations were approx. 0.2 wt.\%. However, $\mathrm{Pb}$ and $\mathrm{Mn}$ were found in higher concentrations, reaching values higher than $1 \mathrm{wt} . \%$ in 18117BV. Sample 17117BV showed the lowest Na values and a slight increase in $\mathrm{Si}$ and $\mathrm{Al}$, being also the only blue tessera in which sulfur was detected, suggesting the occurrence of a heavy alkali leaching phenomenon [78,79]. The whole set of elemental data collected on the blue tesserae seems to match the typical silica-soda-lime Roman glasses, although for these tesserae, the level of $\mathrm{Pb}$ was even higher than the one found for the semi-opaque tesserae and thus the use of cullet or the recycling of glass resulting in the decrease of sodium levels cannot be ruled out [83,84]. Raman investigations evidenced the presence of two calcium antimony opacifying agents, largely used in the Roman world up to the 4th-5th century AD [80], namely $\mathrm{Ca}_{2} \mathrm{Sb}_{2} \mathrm{O}_{7}$ (signals at 482 and $633 \mathrm{~cm}^{-1}$ ) and $\mathrm{CaSb}_{2} \mathrm{O}_{6}$ (signals at 237 and $671 \mathrm{~cm}^{-1}$ ) (Figure 10), the latter being the most frequently found in the samples. The occurrence of both cited compounds provided some clues about glass tesserae production technology since the formation of the trigonal form $\left(\mathrm{CaSb}_{2} \mathrm{O}_{6}\right)$ is kinetically favored at $950{ }^{\circ} \mathrm{C}$, whereas the formation of the cubic form $\left(\mathrm{Ca}_{2} \mathrm{Sb}_{2} \mathrm{O}_{7}\right)$ is more thermodynamically favored at $1100{ }^{\circ} \mathrm{C}$. At intermediate temperatures both compounds coexist. In other words, both firing temperature and time employed in glassmaking may concur to the formation of the cited compounds [100]. 


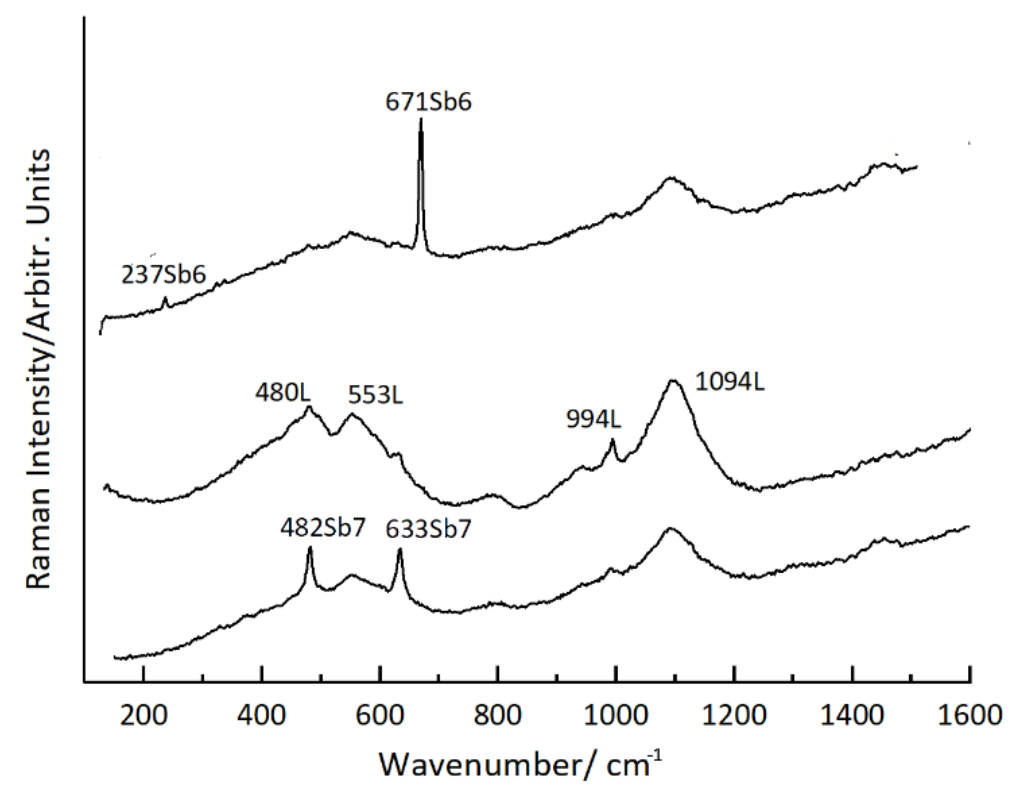

Figure 10. Raman spectra collected from blue glass tesserae, 14117BV, 17117BV and 18117BV samples, in which lazurite (L), and calcium antimonates, $\mathrm{Ca}_{2} \mathrm{Sb}_{2} \mathrm{O}_{7}(\mathrm{Sb} 7)$ and $\mathrm{CaSb}_{2} \mathrm{O}_{6}(\mathrm{Sb} 6)$, signals are identified.

Furthermore, rutile $\left(\mathrm{TiO}_{2}\right.$, signals at 143, 241, 445 and $\left.610 \mathrm{~cm}^{-1}\right)$, and different Si-O bonds of the glassy phase (at 550 and $1093 \mathrm{~cm}^{-1}$, and also at 480 and $1065 \mathrm{~cm}^{-1}$ ) were identified, together with some calcium and/or aluminum-silicate, incorporating cobalt ions or some alkali sulfate $[80,101]$ as indicated by the signals collected at $459,616,637$, $996,1076,1130$ and $1198 \mathrm{~cm}^{-1}$. Since it is known that cobalt is able to impart a dark blue color in the glass matrix even if present at levels of few $\mu \mathrm{g} / \mathrm{g}$, it can be concluded that the samples' deep blue color is due very likely to its occurrence, as the Co amount was found to range from 0.24 to $0.10 \mathrm{wt}$.\%. Indeed, the observed amount of copper (from 0.60 to $0.38 \mathrm{wt} . \%$ ) suggested that it could be also deliberately added to modify the hue imparted by cobalt, actually correlated to the $\mathrm{Cu} / \mathrm{Co}$ ratio employed [27]. Furthermore, it is worth noting that in the surface layer of the 17117BV sample, the worst preserved, the presence of lazurite $\left(\left(\mathrm{Na}_{3} \mathrm{Ca}\left(\mathrm{Si}_{3} \mathrm{Al}_{3}\right) \mathrm{O}_{12} \mathrm{~S}\right)\right.$, signals at 480, 553, 994 and $\left.1094 \mathrm{~cm}^{-1}\right)$ (Figure 10) was commonly found, suggesting the use of lapis lazuli as a blue glass and enamel coloring agent $[102,103]$. The choice of such high-quality materials supported and expanded the archaeological evidence in Room 17, indicating the aim of creating a luxury decoration as the main expression of the representative function of the room.

\subsubsection{Red Opaque Glass Tessera}

The only red opaque glass sample investigated, 15117RV (Figure 5, Table 2), was featured by a surface golden layer, as well as small spherical holes and craters, indicating the occurrence of a macroscopic alteration quite common in archaeological glass [99]. The core piece displayed as its main elements, found by EDXRF, $\mathrm{Si}, \mathrm{Pb}$ and $\mathrm{Na}$ (with amounts of 34, 29 and $14 \mathrm{wt} . \%$, respectively) and, as the minor elements, $\mathrm{Ca}, \mathrm{Fe}, \mathrm{Cu}, \mathrm{Sb}, \mathrm{K}$ and $\mathrm{Al}$, i.e., 7, 5, 4, 2, 1 and $1 \mathrm{wt} . \%$, respectively. These were together with trace elements, minor than $0.5 \mathrm{wt} . \%$, such as $\mathrm{Sn}, \mathrm{Mn}, \mathrm{Sr}$, Ti and $\mathrm{Zn}$. Moreover, rutile $\left(\mathrm{TiO}_{2}\right.$, signals at 143,445 and $\left.609 \mathrm{~cm}^{-1}\right)$, its anatase polymorph $\left(\mathrm{TiO}_{2}\right.$, signals at 143, 193, 396, 512 and $635 \mathrm{~cm}^{-1}$ ) and amorphous silicate of the glassy matrix containing a dispersion of copper nanoparticles (signals at 550, 988 and $1086 \mathrm{~cm}^{-1}$ ) [104,105] were identified by Raman spectroscopy (Figure 11). Due to the typical light strong absorption of copper containing glasses, no other Raman signals were detected for this sample [80]. In addition, since it is known that the combination of $\mathrm{PbO}$ and $\mathrm{SnO}_{2}$ at temperatures above $600{ }^{\circ} \mathrm{C}$, with a $\mathrm{Pb} / \mathrm{Sn}$ ratio around $3.5 \%$, forms $\mathrm{Pb}_{2} \mathrm{SnO}_{4}$ [106], and considering that the 15117RV sample 
displayed a much higher $\mathrm{Pb} / \mathrm{Sn}$ ratio without any compositional difference between the surface and inner parts, the surface golden leaf could have been the result of $\mathrm{Pb}_{2} \mathrm{SnO}_{4}$ formation, which is yellow and also featured by Raman signatures close to anatase $[107,108]$.

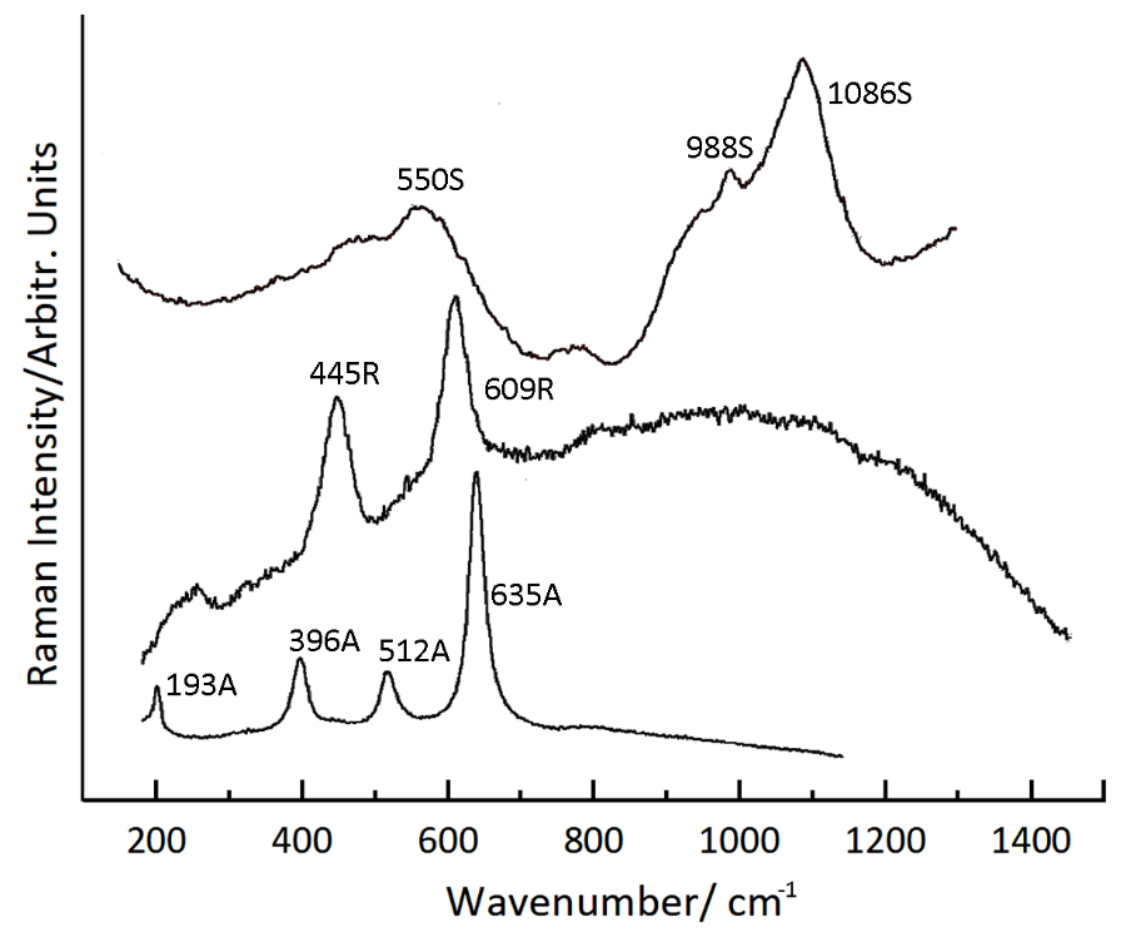

Figure 11. Raman spectra collected from red glass opaque tessera, 15117RV sample, in which anatase (A), rutile (R) and silica of the glassy matrix signals are identified.

The analyses reported mainly two typologies on the red archaeological glasses document, both copper-based, the first where cuprite $\left(\mathrm{Cu}_{2} \mathrm{O}\right)$ was the compound imparting the color, and the other characterized by the presence of micro-sized copper particles into the matrix [101]. Although the detection of copper by the EDXRF could be indicative of both technologies, the Raman analysis could not clarify this point since the copper compound responsible for the red color could not be identified. Anatase was the only compound detected by Raman, able to contribute to the dark red color of the investigated sample [109]. Nevertheless, the whole elemental composition was found to be compatible with the ancient opaque red glasses obtained by the combined use of copper and iron, in a lead-rich matrix [110] or, very likely, with the employment of tin-bronze as a source of metallic copper [27]. The use of copper for glassmaking became known from the 2nd millennium BC, and was largely spread throughout antiquity. The cited glass technology required the capability to strictly control the redox conditions during firing, since the formation of monovalent copper inside the glass matrix could be obtained either by adding proper reducing agents (such as iron) and/or tuning the furnace atmosphere using a limited range of oxygen partial pressures [106]. Furthermore, the addition of $\mathrm{PbO}$ to the recipe of copper-red glass was often used since $\mathrm{PbO}$ increases the density of the flux thus providing a better distribution of copper into the glass matrix, resulting in an intense and homogenous red color [111]. In addition, the use of copper alloy scale as a source of copper, known to be a technology employed in the production of Roman mosaic red tesserae in Italy [112,113], could be discarded due to the low amount of tin found in 15117RV. From all the above considerations, it can be suggested that the 15117RV sample was produced using antimony-based opacifiers, whereas copper was employed to provide the characteristic red color [28]. 


\section{Conclusions}

The first archaeometric investigation on a variety of mosaic tesserae coming from the Roman houses being excavated at Villa San Pancrazio in Taormina has been carried out. For this purpose, the selected non-invasive methodology based on the combination of EDXRF and Raman spectroscopy allowed us to ascertain that the raw materials used by the craftsmen in charge of executing the mosaics were partly natural and partly artificial and provided several additional clues about important historical questions concerning the supplying and production strategies of the workshop.

Significant results have been obtained first for the black and white mosaics covering the ambulatories of Domus 1 as well as several rooms of the same house and of Domus 2a. Chemometric tools used to firstly explore the elemental composition of the tesserae revealed three kinds of white tesserae and different typologies of black samples. While the three kinds of white stones resulted from the following analyses to be compatible with the geochemistry of local carbonatic/dolomitic materials, a more complex pattern emerged for the groups of black tesserae. In fact, other than a first group of black tesserae characterized by a carbonatic nature matching the composition of the local sedimentary dark grey marly limestones, the Raman and XRD investigations clearly indicated that the other black samples, although being all volcanic, were featured by different compositions, so that some of them could be compatible with the geochemistry of the nearby Etna volcanic area, whereas some others seemed to have been imported. Considering the easy availability of sources of volcanic stone in the area, the additional use of non-local materials to obtain the dark tesserae deserves some consideration. It could be explained by either economic or technical and/or aesthetic reasons: in the first case, non-local volcanic stone could have been on sale in the local market as second-use material or, more likely, purchasable at a lower price outside Taormina; this hypothesis would imply that the workshop had a network of commercial contacts wider than the local market. Alternatively, the use of both local and imported volcanic stone, plus the carbonatic_probably local—ones, can be explained in terms of the specific choices of the commissioner or of the craftsmen. This theory seems to be somehow supported by the spatial distribution of the black samples from Domus 1 (as shown in Figure S6), which evidences a discrete use of the black tesserae of the three groups in different areas/rooms of the house. It is not easy to establish what such choices were based on, but they could be related to an awareness of the intrinsic properties of the different kinds of stone, such as their durability, or to an evaluation of different aesthetic effects. Besides, another hint of a certain awareness of differences between tesserae of the same color has been evidenced by the selective use of the less soluble materials (i.e., the dolomite-based tesserae) for the white tesserae of the east ambulatory outdoor pavement. Such clues can offer answers to important archaeological questions regarding the commercial network and/or the technical skills of the workshop active in Taormina, provided that the methods adopted in this study are applied to a wider number of samples.

Other significant results have been obtained from the colored tesserae used in the pavements and niche revetments of some rooms of Domus 1 and 2a, where polychrome mosaics and higher-value materials enhanced a luxurious set and a representative function. The analyses carried out on the tesserae other than white and black, revealed interesting information not only on the employment of natural lithic materials, local or not, but also on the technology used to produce artificial tesserae. The orange tessera was found to be made of pottery; in addition, its elemental composition and the occurrence of diopside, as demonstrated by the Raman analyses, suggested that this sample was obtained by the firing of magnesium-rich clays. The semi-opaque soda-lime-silica glass tesserae collected in Room 17 of Domus 1, in the niche area, displayed a variety of artificial materials made with different technologies and coloring compounds, such as $\mathrm{Cu}$ in a lead-rich matrix to obtain red hues, or $\mathrm{Co}$ and $\mathrm{Cu}$ to obtain deep blue, and antimony-based opacifying agents.

More interestingly, most of the glass tesserae featured a low level of sodium in their composition, strongly indicative of the occurrence of heavy degradation processes which, together with high levels of lead, could also indicate Na-poor original glassmaking with 
the use of cullet, the recycling of glass or the employment of local siliceous sands, quite abundant in the Ragusa coastal area. In addition, the systematic occurrence of unusual Sr levels as the trace element in all the cited semi-opaque glass tesserae could be an interesting starting point to ascertain whether they were locally produced or not.

In conclusion, all these findings provide preliminary clues that shed new light on issues concerning the economic dynamics and technical skills involved in the production process of mosaics, which are still poorly explored in several regions of the Roman Empire, such as in Sicily. Above all, this study demonstrates that crucial questions such as the supplying of raw materials, the network of commercial routes and the assessment of ceramic and glassmaking technologies, can be properly addressed only by an integrated archaeological and chemical perspective.

Supplementary Materials: The following are available online at https:/ / www.mdpi.com/article/10.3390/ cryst11111423/s1, Figure S1: Aerial view of modern Taormina; the white arrow points out the position of the Hotel Villa San Pancrazio (Sicily, Italy). Figure S2: Plan of the Hotel Villa San Pancrazio and its park, showing the position of the Roman houses: in green Domus 1; in grey Domus 2 and 2a; in yellow Domus 3; in purple Roman reservoir. Figure S3: View of Domus 1 after the excavations of the past century. Figure S4: Domus 2, wall paintings of the northern corridor of the courtyard. Figure S5: Domus 1, wall paintings of Room 12. Figure S6: Plan of Domus 1 showing the sampling location of the analyzed white and black tesserae. Table S1: Mosaic tesserae samples from the archaeological area of Villa San Pancrazio (Taormina, Italy). Table S2: EDXRF elemental data (wt.\%) of white and black stone tesserae samples.

Author Contributions: Conceptualization, O.G.-L., L.C. and P.C.; Data curation, O.G.-L., A.I., P.I. and C.B.; Formal analysis, O.G.-L. and P.I.; Funding acquisition, O.G.-L., I.M.-A. and P.C.; Investigation, O.G.-L., G.L., L.C. and P.C.; Methodology, O.G.-L., G.L. and P.C.; Resources, O.G.-L., L.C. and P.C.; Supervision, O.G.-L., L.C. and P.C.; Writing-original draft, O.G.-L., A.I., P.I., G.L., L.C. and P.C.; Writing-review and editing, O.G.-L., I.M.-A., L.C. and P.C. All authors have read and agreed to the published version of the manuscript.

Funding: This work was supported by project IT-742-13 for Consolidated Research Groups, funded by the Basque Country Government. P. Irizar gratefully acknowledges his predoctoral grant (PRE2018085888) from the MINECO Spanish Ministry. O. Gómez-Laserna is grateful to the University of the Basque Country (UPV/EHU) for her postdoctoral contract. P. Cardiano also thanks University of Messina (FFABR UNIME 2020) for funding.

Acknowledgments: The technical support provided by the X-Ray Service (Rocks and Minerals Unit) of SGIker (UPV /EHU, MICINN, GV /EJ, ERDF, and ESF) is gratefully acknowledged as well as the Soprintendenza BB.CC.AA. di Messina for having allowed the material sampling.

Conflicts of Interest: The authors declare no conflict of interest. The funders had no role in the design of the study; in the collection, analyses, or interpretation of data; in the writing of the manuscript, or in the decision to publish the results.

\section{References}

1. Moreno González, M.F. Aspectos técnicos, económicos, funcionales e ideológicos del mosaico romano. An. Arqueol. Cordob. 1995, 6, 113-114. [CrossRef]

2. Blanc-Bijon, V. Comment travaillaient les mosaïstes dans l'Antiquité. Territ. Cult. 2016, 25, 16-41.

3. Wootton, W.T. Mosaic production in 4th-c. Britain: Materials, making and makers at Badminton Park. In Ateliers and Artisans in Roman Art and Archaeology; Kristensen, T.M., Poulsen, B., Eds.; Supplementary Series; JRA: Portsmouth, UK, 2012; Volume 92, pp. 145-168.

4. Mastelloni, M.A.; Tusa, M.E. Pavimenti da uno scavo di A. Salinas (1912). Nota Preliminare. In Atti dell'VIII Colloquio dell'Associazione Italiana per lo Studio e la Conservazione del Mosaico (AISCOM); Guidobaldi, F., Paribeni, A., Eds.; Edizioni del Girasole: Ravenna, Italy, 2001; pp. 689-720.

5. Verità, M.; Lazzarini, L.; Tesser, E.; Antonelli, F. Villa del Casale (Piazza Armerina, Sicily): Stone and glass tesserae in the baths floor mosaics. Archaeol. Anthropol. Sci. 2019, 11, 373-385. [CrossRef]

6. Von Boeselager, D. Antike Mosaiken in Sizilien, Hellenismus und Römische Kaiserzeit, 3rd ed.; Jahrhundert v. Chr.-3. Jahrhundert n. Chr; L'Erma di Bretschneider: Roma, Italy, 1983. 
7. Campagna, L.; Toscano Raffa, A.; Miano, M.; Papale, M.C.; Venuti, M.; Bonanno, S. Lo scavo nella Villa San Pancrazio a Taormina. Relazione preliminare sulle attività delle campagne 2015-2017. Quad. Archeol. Univ. Messina 2017, 8, 131-199.

8. Adlington, L.W.; Gratuze, B.; Schibille, N. Comparison of pXRF and LA-ICP-MS analysis of lead-rich glass mosaic tesserae. J. Archaeol. Sci. Rep. 2020, 34, 102603. [CrossRef]

9. Veneranda, M.; Aramendia, J.; Gomez, O.; Fdez-Ortiz de Vallejuelo, S.; Garcia, L.; Garcia-Camino, I.; Castro, K.; Azkarate, A.; Madariaga, J.M. Characterization of archaeometallurgical artefacts by means of portable Raman systems: Corrosion mechanisms influenced by marine aerosol. J. Raman Spectrosc. 2017, 48, 258-266. [CrossRef]

10. Gómez-Laserna, O.; Prieto-Taboada, N.; Morillas, H.; Arrizabalaga, I.; Olazabal, M.A.; Arana, G.; Madariaga, J.M. Analytical study to evaluate the origin and severity of damage caused by salt weathering in a historical Palace House: The attack of infiltration water. Anal. Methods 2015, 7, 4608-4615. [CrossRef]

11. Gómez-Laserna, O.; Cardiano, P.; Diez-Garcia, M.; Prieto-Taboada, N.; Kortazar, L.; Olazabal, M.A.; Madariaga, J.M. Multi-analytical methodology to diagnose the environmental impact suffered by building materials in coastal areas. Environ. Sci. Pollut. Res. 2018, 25, 4371-4386. [CrossRef]

12. Luo, X.; Gu, Z.; Yu, C.W.; Li, K.; Xiao, B. Preservation of in situ artefacts by local heating in earthen pit in archaeology museum in cold winter. Build. Environ. 2016, 99, 29-43. [CrossRef]

13. Luo, X.; Chang, B.; Tian, W.; Li, J.; Gu, Z. Experimental study on local environmental control for historical site in archaeological museum by evaporative cooling system. Renew. Energy 2019, 143, 798-809. [CrossRef]

14. Colomban, P.; March, G.; Mazerolles, L.; Karmaous, T.; Ayed, N.; Ennabli, A.; Slim, H. Raman identification of materials used for jewellery and mosaics in Ifriqiya. J. Raman Spectrosc. 2003, 34, 205-213. [CrossRef]

15. Gómez-Laserna, O.; Olazabal, M.A.; Morillas, H.; Prieto-Taboada, N.; Martinez-Arkarazo, I.; Arana, G.; Madariaga, J.M. In-situ spectroscopic assessment of the conservation state of building materials from a Palace house affected by infiltration water. J. Raman Spectrosc. 2013, 44, 1277-1284. [CrossRef]

16. Gómez-Laserna, O.; Arrizabalaga, I.; Prieto-Taboada, N.; Olazabal, M.A.; Arana, G.; Madariaga, J.M. In situ DRIFT, Raman, and XRF implementation in a multianalytical methodology to diagnose the impact suffered by built heritage in urban atmospheres. Anal. Bioanal. Chem. 2015, 407, 5635-5647. [CrossRef]

17. Vandenabeele, P.; Donais, M.K. Mobile Spectroscopic Instrumentation in Archaeometry Research. Appl. Spectrosc. 2016, 70, $27-41$. [CrossRef]

18. Martina, I.; Wiesinger, R.; Schreiner, M. Micro-Raman investigations of early stage silver corrosion products occurring in sulfur containing atmospheres. J. Raman Spectrosc. 2013, 44, 770-775. [CrossRef]

19. Chaplin, T.D.; Clark, R.J.H.; Jones, R.; Gibbs, R. Pigment analysis by Raman microscopy and portable X-ray fluorescence (pXRF) of thirteenth to fourteenth century illuminations and cuttings from Bologna. Philos. Trans. R. Soc. A Math. Phys. Eng. Sci. 2016, 374, 20160043. [CrossRef]

20. Costantini, I.; Lottici, P.P.; Bersani, D.; Pontiroli, D.; Casoli, A.; Castro, K.; Madariaga, J.M. Darkening of lead- and iron-based pigments on late Gothic Italian wall paintings: Energy dispersive $\mathrm{X}$-ray fluorescence, $\mu$-Raman, and powder $\mathrm{X}$-ray diffraction analyses for diagnosis: Presence of $\beta-\mathrm{PbO}_{2}$ (plattnerite) and $\alpha-\mathrm{PbO}_{2}$ (scrutinyite). J. Raman Spectrosc. 2020, 51, 680-692. [CrossRef]

21. Marcaida, I.; Maguregui, M.; Morillas, H.; Prieto-Taboada, N.; De Vallejuelo, S.F.O.; Veneranda, M.; Madariaga, J.M.; Martellone, A.; De Nigris, B.; Osanna, M. In situ non-invasive characterization of the composition of Pompeian pigments preserved in their original bowls. Microchem. J. 2018, 139, 458-466. [CrossRef]

22. Veneranda, M.; Fdez Ortiz de Vallejuelo, S.; Prieto-Taboada, N.; Maguregui, M.; Marcaida, I.; Morillas, H.; Martellone, A.; De Nigris, B.; Osanna, M.; Castro, K.; et al. In-situ multi-analytical characterization of original and decay materials from unique wall mirrors in the House of Gilded Cupids, Pompeii. Herit. Sci. 2018, 6, 40. [CrossRef]

23. Alberti, R.; Crupi, V.; Frontoni, R.; Galli, G.; La Russa, M.F.; Licchelli, M.; Majolino, D.; Malagodi, M.; Rossi, B.; Ruffolo, S.A.; et al. Handheld XRF and Raman equipment for the in situ investigation of Roman finds in the Villa dei Quintili (Rome, Italy). J. Anal. At. Spectrom. 2017, 32, 117-129. [CrossRef]

24. Ion, R.M.; Bakirov, B.A.; Kichanov, S.E.; Kozlenko, D.P.; Belushkin, A.V.; Radulescu, C.; Dumala, I.D.; Bucurica, I.A.; Gheboianu, A.I.; Stirbescu, R.M.; et al. Non-Destructive and Micro-Invasive Techniques for Characterizing the Ancient Roman Mosaic Fragments. Appl. Sci. 2020, 10, 3781. [CrossRef]

25. Freitas, R.P.; Coelho, F.A.; Felix, V.S.; Pereira, M.O.; De Souza, M.A.T.; Anjos, M.J. Analysis of 19th century ceramic fragments excavated from Pirenópolis (Goiás, Brazil) using FT-IR, Raman, XRF and SEM. Spectrochim. Acta Part A Mol. Biomol. Spectrosc. 2018, 193, 432-439. [CrossRef]

26. Ricca, M.; Paladini, G.; Rovella, N.; Ruffolo, S.A.; Randazzo, L.; Crupi, V.; Fazio, B.; Majolino, D.; Venuti, V.; Galli, G.; et al. Archaeometric Characterisation of Decorated Pottery from the Archaeological Site of Villa dei Quintili (Rome, Italy): Preliminary Study. Geosci. J. 2019, 9, 172. [CrossRef]

27. Licenziati, F.; Calligaro, T. Study of mosaic glass tesserae from Delos, Greece using a combination of portable $\mu$-Raman and X-ray fluorescence spectrometry. J. Archaeol. Sci. Rep. 2016, 7, 640-648. [CrossRef]

28. Neri, E.; Morvan, C.; Colomban, P.; Guerra, M.F.; Prigent, V. Late Roman and Byzantine mosaic opaque "glass-ceramics" tesserae (5th-9th century). Ceram. Int. 2016, 42, 18859-18869. [CrossRef]

29. Basso, E.; Invernizzi, C.; Malagodi, M.; La Russa, M.F.; Bersani, D.; Lottici, P.P. Characterization of colorants and opacifiers in roman glass mosaic tesserae through spectroscopic and spectrometric techniques. J. Raman Spectrosc. 2014, 45, 238-245. [CrossRef] 
30. Bersani, D.; Conti, C.; Matousek, P.; Pozzi, F.; Vandenabeele, P. Methodological evolutions of Raman spectroscopy in art and archaeology. Anal. Methods 2016, 8, 8395-8409. [CrossRef]

31. Coccato, A.; Bersani, D.; Coudray, A.; Sanyova, J.; Moens, L.; Vandenabeele, P. Raman spectroscopy of green minerals and reaction products with an application in Cultural Heritage research. J. Raman Spectrosc. 2016, 47, 1429-1443. [CrossRef]

32. Cebeci, D.; Wang, P.; Alam, A.; Pinal, R.; Ben-Amotz, D. Photobleaching profile of Raman peaks and fluorescence background. Eur. Pharm. Rev. 2017, 22, 18-21.

33. Zięba-Palus, J.; Michalska, A. Photobleaching as a useful technique in reducing of fluorescence in Raman spectra of blue automobile paint samples. Vib. Spectrosc. 2014, 74, 6-12. [CrossRef]

34. Ricca, M.; Urzì, C.E.; Rovella, N.; Sardella, A.; Bonazza, A.; Ruffolo, S.A.; De Leo, F.; Randazzo, L.; Arcudi, A.; La Russa, M.F. Multidisciplinary Approach to Characterize Archaeological Materials and Status of Conservation of the Roman Thermae of Reggio Calabria Site (Calabria, South Italy). Appl. Sci. 2020, 10, 5106. [CrossRef]

35. Campagna, L. Tauromenium in età imperiale: Nuovi dati dai recenti scavi. In Römisches Sizilien: Stadt und Land Zwischen Monumentalisierung und Ökonomie, Krise und Entwicklung; Belvedere, O., Bergemann, J., Eds.; Palermo University Press: Palermo, Italy, 2018; pp. 285-297.

36. Campagna, L. The Making of the Hellenistic City in Sicily. Some Reflections from the Case Study of Tauromenion. In Cityscapes of Hellenistic Sicily; Trümper, M., Adornato, G., Lappi, T.H., Eds.; Quasar: Roma, Italy, 2019; pp. 55-73.

37. Lentini, M.C.; Vanaria, M.G.; Schneider, K. Mosaici da Taormina. Una difficile tutela. In Atti del XX Colloquio dell'Associazione Italiana per lo Studio e la Conservazione del Mosaico (AISCOM); Angelelli, A., Paribeni, A., Eds.; Scripta Manent: Tivoli, Italy, 2015; pp. 681-693.

38. Muscolino, F. La "Zecca" di Taormina e i mosaici rinvenuti nelle sue adiacenze. In Atti del XX Colloquio dell'Associazione Italiana per lo Studio e la Conservazione del Mosaico (AISCOM); Angelelli, C., Ed.; Scripta Manent: Tivoli, Italy, 2013; pp. 491-500.

39. Spigo, U. I pavimenti della domus di Porta Pasquale a Taormina. Dati preliminari. In Atti del XX Colloquio dell'Associazione Italiana per lo Studio e la Conservazione del Mosaico (AISCOM); Angelelli, C., Ed.; Scripta Manent: Tivoli, Italy, 2004; pp. $399-418$.

40. Spigo, U. Pavimenti della domus di età imperiale romana di Porta Pasquale a Taormina, in Apparati musivi antichi nell'area del Mediterraneo. La Materia e i Segni della Storia. In Atti del I Convegno Internazionale di Studi (I Quaderni di Palazzo Montalbo); Regione Siciliana: Palermo, Italy, 2004; pp. 681-683.

41. Bacci, G.M. Taormina 1. Ricerche archeologiche nell'area urbana. Arch. Stor. Messin. 1980, 38, 335-347.

42. Bacci, G.M. Ricerche a Taormina negli anni 1977-1980. Kokalos 1980, 26-27, 737-748.

43. Bacci, G.M.; Rizzo, C. Attività della Soprintendenza. Taormina. Kokalos 1993, 39-40, 945-951.

44. Campagna, L. Pitture parietali a Tauromenium in età imperiale: Nuovi dati dalle domus di Villa San Pancrazio. In Atti delle XIII Giornate Gregoriane; Caminneci, V., Parello, M.C., Rizzo, M.S., Eds.; Ante Quem: Bologna, Italy, 2021; pp. 9-18.

45. Garcia-Rowe, J.; Saiz-Jimenez, C. Lichens and bryophytes as agents of deterioration of building materials in Spanish cathedrals. Int. Biodeterior. 1991, 28, 151-163. [CrossRef]

46. Morillas, H.; Maguregui, M.; Gómez-Laserna, O.; Trebolazabala, J.; Madariaga, J.M. Could marine aerosol contribute to deteriorate building materials from interior areas of lighthouses? An answer from the analytical chemistry point of view. J. Raman Spectrosc. 2013, 44, 1700-1710. [CrossRef]

47. CNR-ICR. Materiali Lapidei: Campionamento; Comas Grafica: Roma, Italy, 1980.

48. Castro, K.; Pérez-Alonso, M.; Rodríguez-Laso, M.D.; Fernández, L.A.; Madariaga, J.M. On-line FT-Raman and dispersive Raman spectra database of artists' materials (e-VISART database). Anal. Bioanal. Chem. 2005, 382, 248-258. [CrossRef]

49. Dows, R.T. The RRUFF Project: An integrated study of the chemistry, crystallography, Raman and infrared spectroscopy of minerals. In Proceedings of the 19th General Meeting of the International Mineralogical Association, Kobe, Japan, 23-28 July 2006; pp. 8-25.

50. Maguregui, M.; Prieto-Taboada, N.; Trebolazabala, J.; Goienaga, N.; Arrieta, N.; Aramendia, J.; Gomez-Nubla, L.; Sarmiento, A.; Olivares, M.; Carrero, J.; et al. Dispersive Raman spectra database of original and decayed materials belonging to the Natural, Industrial and Cultural Heritage (e-VISNICH database). In Proceedings of the 1st International Congress of Chemistry for Cultural Heritage (ChemCH), Ravenna, Italy, 30 June-3 July 2010; pp. 168-170.

51. Pérez-Alonso, M.; Castro, K.; Madariaga, J.M. Investigation of degradation mechanisms by portable Raman spectroscopy and thermodynamic speciation: The wall painting of Santa María de Lemoniz (Basque Country, North of Spain). Anal. Chim. Acta 2006, 571, 121-128. [CrossRef]

52. Gates-Rector, S.D.; Blanton, T.N. The Powder Diffraction File: A Quality Materials Characterization Database. Powder Diffr. 2019, 34, 352-360. [CrossRef]

53. Barbieri, M.; Bellanca, A.; Neri, R.; Tolomeo, L. Use of strontium isotopes to determine the sources of hydrothermal fluorite and barite from northwestern Sicily (Italy). Chem. Geol. Isot. Geosci. Sect. 1987, 66, 273-278. [CrossRef]

54. Rosell, L.; Orti, F.; Kasprzyk, A.; Playa, E.; Peryt, T.M. Strontium geochemistry of Miocene primary gypsum; Messinian of southeastern Spain and Sicily and Badenian of Poland. J. Sediment. Res. 1998, 68, 63-79. [CrossRef]

55. Mattavelli, L.; Chilingarian, G.V.; Storer, D. Petrography and diagenesis of the taormina formation, gela oil field, sicily (Italy). Sediment. Geol. 1969, 3, 59-86. [CrossRef]

56. Cardiano, P.; Sergi, S.; De Stefano, C.; Loppolo, S.; Piraino, P. Investigations on ancient mortars from the Basilian monastery of Fragalà. J. Therm. Anal. Calorim. 2008, 91, 477-485. [CrossRef] 
57. Halla, F. The free energy of the formation of dolomite from its carbonate components. Sedimentology 1962, 1, 191-199. [CrossRef]

58. Sherman, L.A.; Barak, P. Solubility and Dissolution Kinetics of Dolomite in $\mathrm{Ca}-\mathrm{Mg}-\mathrm{HCO}_{3} / \mathrm{CO}_{3}$ Solutions at $25^{\circ} \mathrm{C}$ and $0.1 \mathrm{MPa}$ Carbon Dioxide. Soil Sci. Soc. Am. J. 2000, 64, 1959-1968. [CrossRef]

59. De Visscher, A.; Vanderdeelen, J. Estimation of the Solubility Constant of Calcite, Aragonite, and Vaterite at $25^{\circ} \mathrm{C}$ Based on Primary Data Using the Pitzer Ion Interaction Approach. Monatsh. Chem. 2003, 134, 769-775. [CrossRef]

60. Kendall, J. The solubility of calcium carbonate in water. Lond. Edinb. Philos. Mag. J. Sci. 1912, 23, 958-976. [CrossRef]

61. Sass, E.; Morse, J.W.; Millero, F.J. Dependence of the values of calcite and aragonite thermodynamic solubility products on ionic models. Am. J. Sci. 1983, 283, 218-229. [CrossRef]

62. Bacci, G.M.; Belfiore, C.; Di Bella, M.; Sabatino, G.; Triscari, M.; Viccaro, M. Volcanic rock fragments as tempers in the ceramic products of Francavilla, Taormina and Naxos (Messina): A key to provenance studies. In Scienza e Beni Culturali; Aiar: Siraccusa, Italy, 2008; p. 1.

63. Cardiano, P.; Sergi, S.; Triscari, M.; Piraino, P. Conservation studies on ornamental and building stones of north-eastern Sicily. Geomineralogical and porosimetric investigations. Ann. Chim. 2001, 91, 41-50.

64. Peccerillo, A. Plio-Quaternary Volcanism in Italy; Springer: Berlin/Heidelberg, Germany; New York, NY, USA, 2005.

65. Critelli, S.; Mongelli, G.; Perri, F.; Martín-Algarra, A.; Martín-Martín, M.; Perrone, V.; Dominici, R.; Sonnino, M.; Najib Zaghloul, M. Compositional and Geochemical Signatures for the Sedimentary Evolution of the Middle Triassic-Lower Jurassic Continental Redbeds from Western-Central Mediterranean Alpine Chains. J. Geol. 2008, 116, 375. [CrossRef]

66. Ferrara, V.; Pappalardo, G. Kinematic analysis of rock falls in an urban area: The case of Castelmola hill near Taormina (Sicily, Italy). J. Geomorphol. 2005, 66, 373-383. [CrossRef]

67. Gnaccolini, M.; Mattavelli, L. Esempi di Sedimentazione Ciclica nella Zona Interna del Complesso di Scogliera Barcis-Cansiglio; Istituti di Geologia e Paleontologia dell’Università degli studi di Milano: Milano, Italy, 1969; pp. 343-363.

68. Messina, A.; Somma, R.; Macaione, E.; Carbone, G.; Careri, G. Peloritani continental crust composition (Southern Italy); Geological and petrochemical evidence. Boll. Soc. Geol. Ital. 2004, 123, 405-441.

69. Perrone, V.; Martín-Algarra, A.; Critelli, S.; Decandia, F.A.; D’Errico, M.; Estevez, A.; Lannace, A.; Lazzarotto, A.; MartínMartín, M.; Martín-Rojas, I.; et al. 'Verrucano' and 'Pseudoverrucano' in the Central-Western Mediterranean Alpine Chains: Palaeogeographical evolution and geodynamic significance. In Tectonics of the Western Mediterranean and North Africa; Moratt, G., Chalouan, A., Eds.; Geological Society: London, UK, 2006; Volume 262, pp. 1-43.

70. Avanzinelli, R.; Elliott, T.; Tommasini, S.; Conticelli, S. Constraints on the Genesis of Potassium-rich Italian Volcanic Rocks from U/Th Disequilibrium. J. Petrol. 2008, 49, 195-223. [CrossRef]

71. Giordano, D.; Nichols, A.R.L.; Potuzak, M.; Di Genova, D.; Romano, C.; Russell, J.K. Heat capacity of hydrous trachybasalt from Mt Etna: Comparison with $\mathrm{CaAl}_{2} \mathrm{Si}_{2} \mathrm{O}_{8}(\mathrm{An})-\mathrm{CaMgSi}_{2} \mathrm{O}_{6}(\mathrm{Di})$ as basaltic proxy compositions. Contrib. Mineral. Petrol. 2015, 170, 48. [CrossRef]

72. Brooks, A.H. Mineral Resources of Alaska, Report on Progress of Investigations; U.S. Government Publishing Office: Washington, DC, USA, 1911.

73. Barone, G.; Crupi, V.; Longo, F.; Majolino, D.; Mazzoleni, P.; Raneri, S.; Venuti, V. A multi-technique approach for the characterization of decorative stones and non-destructive method for the discrimination of similar rocks. X-ray Spectrom. 2014, 43, 83-92. [CrossRef]

74. Pensabene, P. Il teatro di Taormina. In Studio Tematico della Carta del Rischio del Patrimonio Culturale ed Ambientale della Regione Siciliana, 2. Il Teatro Greco Romano di Taormina; Regione Siciliana: Palermo, Italy, 2008; pp. 129-154.

75. Saccà, C.; Saccà, D.; Nucera, P.; De Fazio, A.; De Maria, M.; Somma, R. The main lithoid material origin of the Temple of Hercules in San Marco d' Alunzio (Sicily, Italy). Accad. Peloritana Pericolanti 2007, 85, 1-13. [CrossRef]

76. Cardiano, P.; Loppolo, S.; De Stefano, C.; Pettignano, A.; Sergi, S.; Piraino, P. Study and characterization of the ancient bricks of monastery of "San Filippo di Fragalà" in Frazzanò (Sicily). Anal. Chim. Acta 2004, 519, 103-111. [CrossRef]

77. Silvestri, A.; Molin, G.; Salviulo, G. Archaeological glass alteration products in marine and land-based environments: Morphological, chemical and microtextural characterization. J. Non-Cryst. Solids 2005, 351, 1338-1349. [CrossRef]

78. Gueli, A.M.; Pasquale, S.; Tanasi, D.; Hassam, S.; Lemasson, Q.; Moignard, B.; Pacheco, C.; Pichon, L.; Stella, G.; Politi, G. Weathering and deterioration of archeological glasses from late Roman Sicily. Int. J. Appl. Glass Sci. 2020, 11, 215-225. [CrossRef]

79. Palomar, T.; Oujja, M.; Garcia-Heras, M.; Villegas, M.A.; Castillejo, M. Laser induced breakdown spectroscopy for analysis and characterization of degradation pathologies of Roman glasses. Spectrochim. Acta B 2013, 87, 114-120. [CrossRef]

80. Ricciardi, P.; Colomban, P.; Tournié, A.; Macchiarola, M.; Ayed, N. A non-invasive study of Roman Age mosaic glass tesserae by means of Raman spectroscopy. J. Archaeol. Sci. 2009, 36, 2551-2559. [CrossRef]

81. Degryse, P.; Scott, R.B.; Brems, D. The archaeometry of ancient glassmaking: Reconstructing ancient technology and the trade of raw materials. Perspective 2014, 2, 224-238. [CrossRef]

82. Arletti, R.; Quartieri, S.; Vezzalini, G.; Sabatino, G.; Triscari, M.; Mastelloni, M.A. Archaeometrical analyses of glass cakes and vitreous mosaic tesserae from Messina (Sicily, Italy). J. Non-Cryst. Solids 2008, 354, 4962-4969. [CrossRef]

83. Mastelloni, M.A. Caratterizzazioni dei cromofori in tessere vitree da mosaici di Taormina, Lipari e Tusa, in Apparati Musivi Antichi. La Materia e i Segni della Storia. In Atti del I Convegno Internazionale di Studi, (I Quaderni di Palazzo Montalbo, n. 4); Flaccovio: Palermo, Italy, 2004; pp. 649-653. 
84. Silvestri, A.; Molin, G.; Salviulo, G. Roman and medieval glass from the Italian area: Bulk characterization and relationships with production technologies. Archaeometry 2005, 47, 797-816. [CrossRef]

85. Freestone, I. The Recycling and Reuse of Roman Glass: Analytical Approaches. J. Glass Stud. 2015, 57, $29-40$.

86. Galli, S.; Mastelloni, M.A.; Ponterio, R.; Sabatino, G.; Triscari, M. Raman and scanning electron microscopy and energy-dispersive $\mathrm{X}$-ray techniques for the characterization of colouring and opaquening agents in Roman mosaic glass tesserae. J. Raman Spectrosc. 2004, 35, 622-627. [CrossRef]

87. Areletti, R.; Quartieri, S.; Vezzalini, G. Glass mosaic tesserae from Pompeii: An archeometrical investigation. Period. Mineral. 2006, $75,25-38$.

88. Silvestri, A. The coloured glass of Iulia Felix. J. Archaeol. Sci. 2008, 35, 1489-1501. [CrossRef]

89. Freestone, I.C.; Leslie, K.A.; Thirlwall, M.; Gorin-Rosen, Y. Strontium Isotopes in the Investigation of Early Glass Production: Byzantine and Early Islamic Glass from the Near East. Archaeometry 2003, 45, 19-32. [CrossRef]

90. Iovino, M.R.; Maniscalco, L.; Pappalardo, G.; Pappalardo, L.; Puglisi, D.; Rizzo, F.; Romano, F.P. Archaeological Volcanic Glass from The Site of Rocchicella (Sicily, Italy). Archaeometry 2008, 50, 474-494. [CrossRef]

91. Barone, G.; Giudice, A.L.O.; Mazzoleni, P.; Pezzino, A.; Barilaro, D.; Crupi, V.; Triscari, M. Chemical characterization and statistical multivariate analysis of ancient pottery from Messina, Catania, Lentini and Siracusa (Sicily). Archaeometry 2005, 47, 745-762. [CrossRef]

92. Martin, F.F.; Barca, D.; Posedi, I. Evidencing Human Occupation of a Small Island Through Ancient Glass: The Case of Ustica (Palermo, Italy). Open Archaeol. 2020, 6, 124-150. [CrossRef]

93. Brems, D.; Ganio, M.; Latruwe, K.; Balcaen, L.; Carremans, M.; Gimeno, D.; Silvestri, A.; Vanhaecke, F.; Muchez, P.; Degryse, P. Isotopes on the beach, part 1: Strontium isotope ratios as a provenance indicator for lime raw material used in roman glass-making. Archaeometry 2013, 55, 214-234. [CrossRef]

94. Brems, D.; Degryse, P. Trace element analysis in provenancing Roman glass-making. Archaeometry 2014, 56, 116-136. [CrossRef]

95. Baino, F.; Quaglia, A. Evidences of glass-ceramic white opaque tesserae from Roman age: A thermo-analytical approach. Mater. Lett. 2012, 74, 194-196. [CrossRef]

96. Kaplan, Z.; Ipekoglu, B.; Boke, H. Physicochemical properties of glass tesserae in roman terrace house from ancient Antandros (Base glass, opacifiers and colorants). Mediterr. Archaeol. Archaeom. 2017, 17, 141-157. [CrossRef]

97. Aulinas, M.; Garcia-Valles, M.; Gimeno, D.; Fernandez-Turiel, J.L.; Ruggieri, F.; Pugés, M. Weathering patinas on the medieval (S. XIV) stained glass windows of the Pedralbes monastery (Barcelona, Spain). Environ. Sci. Pollut. Res. 2009, 16, 443-452. [CrossRef]

98. Rampazzi, L. Calcium oxalate films on works of art: A review. J. Cult. Herit. 2019, 40, 195-214. [CrossRef]

99. Sánchez, A.; Tuñón, J.; Montejo, M.; Amate, P.; Ceprián, B.; Rousaki, A.; Costa, M.; Saelens, D.; Lycke, S.; Vandenabeele, P. First insights into the archaeometric analysis of the Los Amores Mosaic in Cástulo (Linares, Spain): The Judgement of Paris. Herit. Sci. 2021, 9, 8. [CrossRef]

100. Lahlil, S.; Biron, I.; Cotte, M.; Susini, J.; Menguy, N. Synthesis of calcium antimonate nano-crystals by the 18th dynasty Egyptian glassmakers. Appl. Phys. A 2010, 98, 1. [CrossRef]

101. Donais, M.K.; Van Pevenage, J.; Sparks, A.; Redente, M.; George, D.B.; Moens, L.; Vincze, L.; Vandenabeele, P. Characterization of Roman glass tesserae from the Coriglia excavation site (Italy) via energy-dispersive X-ray fluorescence spectrometry and Raman spectroscopy. Appl. Phys. A 2016, 122, 1050. [CrossRef]

102. Bicchieri, M.; Nardone, M.; Russo, P.A.; Sodo, A.; Corsi, M.; Cristoforetti, G.; Palleschi, V.; Salvetti, A.; Tognoni, E. Characterization of azurite and lazurite based pigments by laser induced breakdown spectroscopy and micro-Raman spectroscopy. Spectrochim. Acta B 2001, 56, 915-922. [CrossRef]

103. Caggiani, M.C.; Colomban, P.; Valotteau, C.; Mangone, A.; Cambon, P. Mobile Raman spectroscopy analysis of ancient enamelled glass masterpieces. Anal. Methods 2013, 5, 4275-4522. [CrossRef]

104. Colomban, P.; Schreiber, H.D. Raman signature modification induced by copper nanoparticles in silicate glass. J. Raman Spectrosc. 2005, 36, 884-890. [CrossRef]

105. Colomban, P.; Tournié, A.; Ricciardi, P. Raman spectroscopy of copper nanoparticle-containing glass matrices: Ancient red stained-glass windows. J. Raman Spectrosc. 2009, 40, 1949-1955. [CrossRef]

106. Zhao, H.X.; Li, Q.H.; Liu, S.; Gan, F.X. Characterization of microcrystals in some ancient glass beads from china by means of confocal Raman microspectroscopy. J. Raman Spectrosc. 2013, 44, 643-649. [CrossRef]

107. Arletti, R.; Fiori, C.; Vandini, M. A study of glass tesserae from mosaics in the monasteries of Daphni and Hosios Loukas (Greece). Archaeometry 2010, 52, 796-815. [CrossRef]

108. Vataj, E.; Hobdari, E.; Röhrs, S.; Vandenabele, P.; Civici, N. Analytical characterization of glass tesserae from mosaics of early Christian basilicas in Albania. Appl. Phys. A 2017, 123, 76. [CrossRef]

109. Bowles, J.F.W. Oxides. In Encyclopedia of Geology, 2nd ed.; Alderton, D., Elias, A.E., Eds.; Academic Press Inc.: London, UK, 2021; pp. 428-441.

110. Santagostino Barbone, A.; Gliozzo, E.; D’acapito, F.; Memmi Turbanti, I.; Turchiano, M.; Volpe, G. The sectilia panels of Faragola (Ascoli Satriano, Southern Italy): A multi-analytical study of the red, orange and yellow glass slabs. Archaeometry 2008, 50, 451-473. [CrossRef] 
111. Welter, N.; Schüssler, U.; Kiefer, W. Characterisation of inorganic pigments in ancient glass beads by means of Raman microspectroscopy, microprobe analysis and X-ray diffractometry. J. Raman Spectrosc. 2007, 38, 113-121. [CrossRef]

112. Boschetti, C. Vitreous Materials in Early Mosaics in Italy: Faience, Egyptian Blue, and Glass. J. Glass Stud. 2011, 53, 59-91.

113. Di Bella, M.; Quartieri, S.; Sabatino, G.; Santalucia, F.; Triscari, M. The glass mosaics tesserae of "Villa del Casale" (Piazza Armerina, Italy): A multi-technique archaeometric Study. Archaeol. Anthropol. Sci. 2014, 6, 345-362. [CrossRef] 